\title{
Alterations of Transcription of Genes Coding Anti-oxidative and Mitochondria-Related Proteins in Amyloid $\beta$ Toxicity: Relevance to Alzheimer's Disease
}

\author{
Magdalena Cieślik ${ }^{1}$ - Grzegorz A. Czapski ${ }^{1}$ Sylwia Wójtowicz ${ }^{1}$ - Iga Wieczorek ${ }^{2}$ • Przemysław L. Wencel ${ }^{2}$. \\ Robert P. Strosznajder ${ }^{2}$ • Vivian Jaber ${ }^{3}$ • Walter J. Lukiw ${ }^{3,4} \cdot$ Joanna B. Strosznajder $^{1}$ (D)
}

Received: 24 June 2019 / Accepted: 23 October 2019 / Published online: 16 November 2019

(C) The Author(s) 2019

\begin{abstract}
A growing body of evidence indicates that pathological forms of amyloid beta $(A \beta)$ peptide contribute to neuronal degeneration and synaptic loss in Alzheimer's disease (AD). In this study, we investigated the impact of exogenous $A \beta_{1-42}$ oligomers $(\mathrm{A} \beta \mathrm{O})$ and endogenously liberated $\mathrm{A} \beta$ peptides on transcription of genes for anti-oxidative and mitochondria-related proteins in cell lines (neuronal SH-SY5Y and microglial BV2) and in brain cortex of transgenic $\mathrm{AD}(\mathrm{Tg}-\mathrm{AD})$ mice, respectively. Our results demonstrated significant $\mathrm{A} \beta \mathrm{O}$-evoked changes in transcription of genes in SH-SY5Y cells, where A $\beta \mathrm{O}$ enhanced expression of Sod1, Cat, $m t-N d 1, B c l 2$, and attenuated Sirt5, Sod2 and Sdha. In BV2 line, A $\beta O$ increased the level of mRNA for Sod2, Dnm1l, Bcl2, and decreased for Gpx4, Sirt1, Sirt3, mt-Nd1, Sdha and Mfn2. Then, A $\beta O$ enhanced free radicals level and impaired mitochondrial membrane potential only in SH-SY5Y cells, but reduced viability of both cell types. Inhibitor of poly(ADP-ribose)polymerase- 1 and activator of sirtuin-1 more efficiently enhanced viability of SH-SY5Y than BV2 affected by A $\beta O$. Analysis of brain cortex of Tg-AD mice confirmed significant downregulation of Sirt1, Mfnl and $m t-N d 1$ and upregulation of Dnm1l. In human AD brain, changes of microRNA pattern (miRNA-9, miRNA-34a, miRNA-146a and miRNA-155) seem to be responsible for decrease in Sirt1 expression. Overall, our results demonstrated a diverse response of neuronal and microglial cells to $A \beta O$ toxicity. Alterations of genes encoding Sirt1, Mfn1 and Drp1 in an experimental model of AD suggest that modulation of mitochondria dynamics and Sirt1, including miRNA strategy, may be crucial for improvement of AD therapy.
\end{abstract}

Keywords Neuronal cells $\cdot$ Microglial cells $\cdot$ Amyloid beta $\cdot$ Alzheimer's disease $\cdot$ Gene expression $\cdot$ miRNA-146a

Magdalena Cieślik and Grzegorz A. Czapski contributed equally to this work.

Joanna B. Strosznajder

jstrosznajder@imdik.pan.pl

1 Department of Cellular Signaling, Mossakowski Medical Research Centre Polish Academy of Sciences, Pawińskiego 5, 02-106 Warsaw, Poland

2 Laboratory of Preclinical Research and Environmental Agents, Mossakowski Medical Research Centre Polish Academy of Sciences, Pawińskiego 5, 02-106 Warsaw, Poland

3 LSU Neuroscience Center, Louisiana State University Health Sciences Center, New Orleans, LA 70112, USA

4 Bollinger Professor of Alzheimer's disease, LSU Neuroscience Center and Departments of Neurology and Ophthalmology, Louisiana State University Health Sciences Center, New Orleans, LA 70112, USA

\section{Introduction}

The amyloid beta $(\mathrm{A} \beta)$ cascade hypothesis of Alzheimer's disease (AD), which was proposed originally by Hardy and Allsop [1], assumes that imbalance between production and clearance of $A \beta$ in the brain leads to its accumulation, oligomerization, aggregation and formation of $A \beta$ plaques. $A \beta$ oligomers trigger a detrimental cascade leading inevitably to inflammatory neurodegeneration and dementia. More recent data demonstrated that small $A \beta$ oligomers are the most toxic conformers of this peptide [2-4]. Correlation between level of $A \beta$ oligomers and cognitive dysfunction in experimental studies supports amyloidogenic hypothesis of AD [5]. Oxidative stress and mitochondrial dysfunction play the most important role in the pathomechanism of AD. Several studies have also demonstrated the important role of the inflammatory processes in AD pathology [6-9]. 
In the brain, immune system is represented by microglial cells and the roles of these cells in the pathomechanism of AD are complex and not fully elucidated [10]. Activation of microglia, as a result of $\mathrm{A} \beta$ plaque deposition, leads to release of pro-inflammatory mediators and, in consequence, to further damaging brain tissue. On the other hand, microglia may internalize and degrade $A \beta$ deposits, but this clearance capacity is lost in the presence of high levels of $A \beta$ [11]. The recent studies extended our understanding of the involvement of microglia in AD pathology and identified detailed roles of microglia in synaptic stripping, neuronal loss and cognitive decline [12, 13].

Healthy and fit microglial cells seem to be a prerequisite for developing successful strategies for preventing and reducing $\mathrm{A} \beta$ peptide toxicity and inflammatory reactions in AD. The necessary condition of microglial well-being is the correct function of mitochondria. Deficiency of mitochondrial ATP may lead to apoptosis and declining microglia function in protecting surrounding neurons against $\mathrm{A} \beta$ toxicity [14]. Mitochondrial dysfunction, one of the earliest alterations of $\mathrm{AD}$, is proposed to be crucial in brain aging and pathogenesis/ progression of AD [15-18]. Mitochondria are the major source of reactive oxygen species (ROS) in the cell, but also the main target of ROS. A $\beta$ accelerates ROS generation and possibly triggers a 'vicious cycle': ROS — mitochondrial impairment-ROS [19-21]. It is known that superoxide dismutase 2 (SOD2) and other enzymes, glutathione peroxidase (GPX), glutathione reductase (GR) and sirtuins (mammalian class III histone deacetylases), are engaged in anti-oxidative defence. Among the most important early molecular changes in AD is downregulation of Sirt1 and Sirt3. Also, mitochondria sirtuins (Sirt) play important roles in the regulation of transcription and activity of several anti-oxidative enzymes such as SOD2 and catalase [22, 23]. These both enzymes are implicated in metabolic control, mitochondria function and longevity by deacetylation of histones, transcription factors and other proteins, including anti-oxidative enzymes [23]. Sirt3 may directly deacetylate and stabilize 8-oxoguanidineDNA glycosylase 1 (OGG1), a base repair mitochondrial and nuclear enzyme, promoting its capacity to repair mtDNA [23, 24]. Sirt1 plays important role in regulation of peroxisome proliferator-activated receptor-gamma coactivator 1 alpha (PGC1- $\alpha$ ), mitochondria biogenesis and mitophagy [25-28]. Moreover, Sirt1 is involved in regulation of amyloid precursor protein (APP) metabolism and A $\beta$ level [26, 27]. A $\beta$-evoked decrease of Sirt1 and Sirt3 is responsible for upregulation of Tau level and acetylation [29, 30]. On the other hand, overexpression of Sirtl significantly attenuated $\mathrm{A} \beta$-evoked NF- $\mathrm{KB}$ signalling and protected against microglia-dependent neurodegeneration [31]. Moreover, neuroprotective and antiinflammatory effects of resveratrol are likely related to its ability to activate sirtuins [32]. These enzymes are crucial in protection of mitochondria against dysfunction induced by
$\mathrm{A} \beta[27,33]$. However, several studies supported 'mitochondria cascade hypothesis for sporadic AD' which underlined that primary mitochondria dysfunction is upstream of $A \beta$ deposition and toxicity in pathogenesis of $\mathrm{AD}[16,17]$. The mechanisms by which $A \beta$ oligomers affect mitochondria remain not entirely understood. It was recently demonstrated that $\mathrm{A} \beta$ evokes destabilization of mitochondrial proteome, mainly by impairment of pre-protein maturation [34]. Also, impairment of mitochondrial dynamics was demonstrated both in $\mathrm{AD}$ patients and in $\mathrm{A} \beta$ toxicity and oxidative stress [35-39]. Mitochondrial dynamics is regulated mainly by highly evolutionary conserved GTP-ases: dynamin-related protein 1 (Drp1), mitofusins 1 and 2 (Mfn1 and Mfn2) and optical atrophy 1 (Opa1) [40]. These all proteins participate in controlling assembly and stability of respiratory chain supercomplexes, in remodelling of mitochondrial structure and distribution of mitochondria through neuronal bodies, axons, dendrites and synapses [41-43]. Several molecular mechanisms are engaged in Drp1-dependent mitochondrial fragmentation. Recently, Manczak at al. [44] demonstrated the protective effects of reduced Drp1 against $A \beta$-induced mitochondria dysfunction and synaptic damage in murine AD model. Their findings suggest that partial reduction of Drp1 decreases $A \beta$ production, mitochondria dysfunction, dynamics and also synaptic activity in Tg2576 AD mouse models.

The impact of oligomeric $A \beta$ on expression of mitochondria-related genes in microglia has never been evaluated carefully. Global alterations of gene transcription in brain tissue may not reflect subtle differences in various cell populations in the brain. To overcome this problem, we analysed $\mathrm{A} \beta$-evoked alterations of gene expression separately in two cell lines: microglial BV2 and neuronal SH-SY5Y. To verify in vitro data, we investigated also changes of gene expression in transgenic murine $\mathrm{AD}$ model and in human $\mathrm{AD}$ brain tissue.

\section{Material and Methods}

\section{Chemicals}

HFIP-treated amyloid $\beta_{1-42}$ (Cat. No. A-1163-2) was obtained from rPeptide (rPeptide, Bogart, GA, USA). MitoScreen (JC-1) kit was from BD Biosciences (San Jose, CA, USA). Reagents for reverse transcription (High Capacity RNA-tocDNA Master Mix) and quantitative PCR (Taqman Assays and Gene Expression Master Mix) were from Applied Biosystems (Foster City, CA, USA). Serum-free NeurobasalA medium and supplement B27 were from Thermo Fisher Scientific Inc., MA USA. BD Protease inhibitor cocktail Complete was obtained from Roche Diagnostics $\mathrm{GmbH}$ (Mannheim, Germany). Olaparib, SRT1720, Dulbecco's 
modified Eagle's medium (DMEM), foetal bovine serum (FBS), horse serum (HS), penicillin, streptomycin, glutamine, 3-(4,5-dimethyl-2-tiazolilo)-2,5-diphenyl-2H-tetrazolium bromide (MTT), TRI-reagent, DNase I, DTT, collagen, anhydrous DMSO and all other reagents were obtained from Sigma-Aldrich (St. Louis, MO, USA).

\section{Cell Culture and Treatment}

Murine microglial BV2 cells obtained as a gift from Prof. R. Donato (Department of Experimental Medicine and Biochemical Sciences, University of Perugia) and human neuroblastoma SH-SY5Y cells purchased from European Collection of Authenticated Cell Culture, Sigma-Aldrich (St. Louis, MO, USA), treated with Amyloid $\beta$ oligomers (A $\beta \mathrm{O}$ ) were used as in vitro model that recapitulates part of the $\mathrm{AD}$ pathology. The BV2 cells were cultured in RPMI supplemented with 5\% heat-inactivated FBS, $2 \mathrm{mM}$ L-glutamine, $50 \mathrm{U} /$ $\mathrm{ml}$ penicillin, $50 \mu \mathrm{g} / \mathrm{ml}$ streptomycin in $5 \% \mathrm{CO}_{2}$ atmosphere at $37{ }^{\circ} \mathrm{C}$. The SH-SY5Y cells were cultured in F12/MEM medium supplemented with $15 \%$ heat-inactivated FBS, $1 \%$ non-essential amino acids, $50 \mathrm{U} / \mathrm{ml}$ penicillin, and $50 \mu \mathrm{g} / \mathrm{ml}$ streptomycin as well as L-glutamine in $5 \% \mathrm{CO}_{2}$ atmosphere at $37^{\circ} \mathrm{C}$

Amyloid $\beta$ oligomerization was performed as described previously [45-47]. Additionally, $A \beta_{1-42}$ with scrambled sequence ( $\mathrm{A} \beta \mathrm{scr}$, the same composition of amino acids but in random order), which was subjected to the same oligomerization protocol, was used as a negative control (data not shown). To avoid binding of $A \beta$ by serum albumins, all experiments were performed in serum-free Neurobasal-A medium with B27 supplement. Equal BV2 and SH-SY5Y cell numbers were seeded into dishes or 96-well collagen-coated plates and after $24 \mathrm{~h}$, they were treated for $24-48 \mathrm{~h}$ with freshly prepared oligomeric $\mathrm{A} \beta(1 \mu \mathrm{M}$, the concentration was chosen after the former analysis of the cell survival curve) or with specified compound administered 5 min before $A \beta$. Olaparib $(3.3 \mu \mathrm{M})$, an inhibitor of PARP, and SRT1720 $(0.1$ $\mu \mathrm{M})$, an activator SIRT, were dissolved in DMSO [48]. Appropriate solvent was added to respective controls.

\section{Mice Tg-AD Model}

Female FVB-Tg(Thy1; APP LD2/B6) mice, aged 12 months, were used. The animals overexpressed human $A \beta P P$ with the 'London' V717I mutation under control of a fragment of Thy 1 promoter with specificity towards brain and spinal cord neurons $\left(\mathrm{APP}^{+}\right)$. Mice that did not inherit the transgene were used as controls $\left(\mathrm{APP}^{-}\right)$. Mice were bred under specific pathogenfree (SPF) conditions by the Animal House of the Mossakowski Medical Research Centre PAS, Warsaw, Poland. The mice were housed in controlled temperature and humidity conditions and 12-h light/dark cycle. The protocol was approved by the Warsaw Local Ethics Committee for Animal Experimentation. All applicable international, national and/or institutional guidelines for the care and use of animals were followed. All efforts were made to minimize suffering and to reduce the number of animals used. The experiments were performed in accordance with good laboratory practice protocols and quality assurance methods.

\section{Human Neocortical Tissue Samples}

Post-mortem human neocortical tissues were handled in strict accordance with the ethics review board policies at donor institutions, and the Institutional Biosafety Committee/ Institutional Review Board (IBC/IRB) Committee's ethical guidelines (IBC\#12323; IRB\#6774) at the Louisiana State University Health Sciences Centre, School of Medicine, New Orleans LA 70112 USA.

\section{Determination of Cell Survival (MTT test)}

Cellular viability and mitochondrial function were measured by the reduction of 3-(4,5-dimethyl-2-tiazolilo)-2,5-diphenyl$2 \mathrm{H}$-tetrazolium bromide (MTT) to formazan as described previously [45].

\section{Measurement of the Level of Intracellular ROS}

Measurement of the free radicals level was carried out using fluorescent indicator 2',7'-dichlorodihydrofluorescein diacetate $\left(\mathrm{H}_{2} \mathrm{DCF}-\mathrm{DA}\right)$ (Cayman Chemical Company), as described previously [46]. DCF fluorescence was measured using a microplate reader FLUOstar Omega (Ortenberg, Germany) at $485 \mathrm{~nm}$ ex. $/ 538 \mathrm{~nm}$ em.

\section{Determination of Mitochondrial Membrane Potential $(\Delta \Psi \mathrm{m})$}

Analysis of mitochondrial membrane potential $(\Delta \Psi \mathrm{m})$ was performed by using JC-1 BD MitoScreen (JC-1) kit according to the manufacturer's instructions. The ratio red/green fluorescence is dependent on the mitochondrial membrane potential. Stained cells (10,000 per analysis) were examined on BD FACS Canto II flow cytometer. Cells incubated in the presence of protonophore and uncoupler of oxidative phosphorylation, carbonyl cyanide 3-chlorophenylhydrazone (CCCP), was used as positive control.

\section{Analysis of Gene Expression}

RNA was isolated by using TRI reagent and purified by using DNase I according to the manufacturer's instructions (SigmaAldrich). Reverse transcription was performed by using High Capacity cDNA Reverse Transcription Kit according to the 
manufacturer's protocol (Applied Biosystems). The level of mRNA for studied genes was analysed by using TaqMan Gene Expression Assays (Applied Biosystems).

$\operatorname{Bax}(\mathrm{Hs} 00150269 \mathrm{~m} 1, \mathrm{Mm} 00432051 \mathrm{~m} 1), B c l 2$ (Hs00608023_m1, Mm00477631_m1), Cat (Hs0056308 m1, Mm00437992 m1), Dnmll (Hs 01552605 m1, Mm01342903_m1), Fis 1 (Hs00211420_m1, Mm00481580_m1), Gpx4 (Hs00989766_g1, Mm00515041_m1), Mfn 1 (Hs00966851_m1, Mm00612599_m1), Mfn2 (Hs00208382_m1, Mm00500120_m1), mt-Co1 (Hs02596864_m1, Mm04225243_g1), mt-Cytb (Hs02596867_s1, Mm04225271_g1), mt-Nd1 (Hs 02596873 _s1, Mm04225274_s1), Opal (Hs01047018_m1, Mm01349707_g1), Sdha (Hs00417200_m1, Mm01352366_m1), Sirt1 (Hs01009005_m1, Mm00490762_m1), Sirt3 (Hso0953477_m1, Mm00452131_m1), Sirt4 (Hs00202033_m1, Mm01201915_m1), Sirt5 (Hso0978335_m1, Mm01351576_m1), Sod1 (Hs00533490_m1, Mm0134423_g1) and Sod2 (Hs00167309_m1, Mm01313000_m1). After initial analysis of threshold cycle values (Ct), Actb (s99999903_m1, ACTB_4352341E) was used as a reference gene. Quantitative PCR was performed on an Applied Biosystems 7500 Real-Time PCR System using TaqMan Gene Expression Master Mix according to the manufacturer's instructions. The relative levels of mRNA were calculated using the $\Delta \Delta \mathrm{Ct}$ method.

\section{RNA Purity Statement}

The RNA used in these experiments was of exceptionally high quality; only short post-mortem interval (PMI) human brain tissues were used with PMIs of $\sim 3 \mathrm{~h}$ or less. RNA quality was assessed using an Agilent 2100 Bioanalyzer (Agilent Technologies, Santa Clara CA, USA); the mean RNA integrity number (RIN) used in these experiments was between 8.05 and 8.1; all RNAs used had an RNA A260/280 of between 2.05 and 2.11; all RNA 28S/18S ratios ranged between 1.4 and 1.6, and the average RNA yield ranged between 1.2 and 1.5 total $\mu \mathrm{g} \mathrm{RNA} / \mathrm{mg}$ of wet weight of brain tissue. Importantly, there was no significant difference in RNA A260/280, RNA 28S/18S ratios or total RNA yield between the control and AD groups.

\section{miRNA Analysis of AD Brain Tissues, miRNA-mRNA Linking Assay and Bioinformatics Analysis}

The microRNA (miRNA)-array analysis of three controls versus three AD brains; age- (mean control age $78.4 \pm 5.7$ years $N$ $=3 ;$ mean $\mathrm{AD}$ age $79.3 \pm 9.2$ years $N=3$ ), gender- (all female) and post-mortem interval (PMI)-matched controls and $\mathrm{AD}$ brain temporal lobes was performed. Isolation, quality control, purification, quantification and statistical analysis of brainenriched miRNA-9, miRNA-34a, miRNA-146a, miRNA155 and mRNA were undertaken as previously described $[49,50]$. All human brain tissue analysis and miRNA analysis were performed as previously described $[49,50]$.

\section{Assessment of Enzymatic Activity of Complex IV of Mitochondrial Respiratory Chain}

Activity of cytochrome c oxidase (COX) in cell lysate was measured according to Spinazzi et al. [51]. Cells (about $5 \times 10^{6}$ ) were collected, washed three times with PBS, and cell pellet was flash-frozen in liquid nitrogen and stored at $-80{ }^{\circ} \mathrm{C}$ until analysis. To prepare lysate, pellet was suspended in $0.4 \mathrm{ml}$ of $20 \mathrm{mM}$ phosphate buffer $(\mathrm{pH}$ 7.5) and homogenized by passing through the needle using $1 \mathrm{ml}$ syringe until homogeneous solution appeared. Then, the cell lysate was three times frozen and then thawed. Cytochrome $\mathrm{c}$ was reduced by incubation in the presence of $0.5 \mathrm{mM}$ DTT for $20 \mathrm{~min}$ at room temperature in dark, the efficacy of cytochrome $\mathrm{c}$ reduction was checked by calculating the ratio of the absorbance $550 \mathrm{~nm} / 565 \mathrm{~nm}$ (ratio $>6$ indicates effective reduction). To measure cytochrome c oxidase activity, $40 \mu \mathrm{l}$ of lysate was incubated with $25 \mu \mathrm{M}$ reduced cytochrome $\mathrm{c}$ in $25 \mathrm{mM}$ phosphate buffer $\mathrm{pH} 7.0$ at room temperature. The decrease of absorbance at $550 \mathrm{~nm}$ was measured during $3 \mathrm{~min}$. The extinction coefficient for reduced cytochrome $\mathrm{c}$ is $18.5 \mathrm{mM}^{-1} \times \mathrm{cm}^{-1}$.

\section{Statistical Analysis}

The results were expressed as mean values \pm S.E.M. miRNA array data were analysed as previously described [50] using a two-way factorial analysis of variance ( $p$, ANOVA) with programs and procedures in the SAS language (Statistical Analysis Institute, Cary, NC, USA). Other data were analysed using Student $t$ test or one-way ANOVA with Bonferroni post hoc test among multiple groups by using GraphPad Prism version 5.0 (Graph Pad Software, San Diego, CA, USA). $P$ values $<0.05$ were considered significant.

\section{Results}

\section{Alterations of ROS Formation, Mitochondrial Membrane Potential and Viability of BV2 and SH-SY5Y cells}

The previous studies demonstrated the significant role of mitochondrial dysfunction in AD-related pathology. In our study, 
we used $1 \mu \mathrm{M} \mathrm{A} \beta$ which contains mostly monomers and small-size oligomeric assemblies, mainly trimers and tetramers. Characteristics of our preparation of $A \beta$ oligomers $(\mathrm{A} \beta \mathrm{O})$ were published previously [45-47]. To identify cell type-specific responses, two cell lines were compared: neuronal-like SH-SY5Y and microglial BV2. To study the effect of $A \beta O$, both cell lines were treated in the same medium (Neurobasal A supplemented with B27) to exclude milieuevoked differences.

As shown on Fig. 1a, after 24-h treatment with $\mathrm{A} \beta \mathrm{O}$, increased ROS formation was observed solely in SH-SY5Y ( $p=$ 0.008 ), but not in BV2 cells. Correspondingly, $A \beta$-evoked disruption of mitochondrial membrane potential was observed in SH-SY5Y cells ( $p=0.0231)$, but not in BV2 cells (Fig. 1b). However, $24 \mathrm{~h}$ incubation in the presence of $1 \mu \mathrm{M} \mathrm{A} \beta \mathrm{O}$ evoked significant decrease of cell viability, both in SHSY5Y $(p<0.0001)$ and BV2 $(p<0.0001)$ cell line (Fig. 1c, d). Prolonged incubation $(48 \mathrm{~h})$ did not potentiate this effect.

\section{Alterations of Expression of Genes Related to Antioxidative Defence and Mitochondria in BV2 and SH-SY5Y cells}

Consistently, transcription of proteins involved in antioxidative defence was different in SH-SY5Y and BV2 cells. After $24 \mathrm{~h}$ incubation, significant increase (up to $370 \%$ of control) in the level of mRNA for mitochondrial $\operatorname{Sod} 2(p=0.006)$ and decrease in the level of mRNA for Gpx4 ( $p=0.016)$ was observed exclusively in BV2 cells (Fig. 2a). Expression of other tested genes (Sod1 and Cat) was not affected by $24 \mathrm{~h}$ incubation in the presence of A $\beta O$. After $48 \mathrm{~h}$ treatment, Sod 2 mRNA level raised to ca. $700 \%$ in BV2 cells ( $p=0.0038)$, but in SH-SY5Y, it was slightly reduced ( $p=0.0171$ ) (Fig. 2b). On the contrary, at this time-point, transcription of Sod1 was increased in SH-SY5Y cells $(p=0.0481)$, but not in BV2 cells. Similarly, mRNA level for Cat was also increased only in SH-SY5Y cells $(p=0.0366)$. Expression of gene for Gpx4 was not affected by $A \beta$ at this time-point.
Fig. 1 The effect of $\mathrm{A} \beta \mathrm{O}$ on the level of reactive oxygen species, mitochondrial membrane potential $(\Delta \Psi \mathrm{m})$, and viability of SH-SY5Y and BV2 cells. SHSY5Y and BV2 cells were incubated in the presence of oligomeric $\mathrm{A} \beta_{1-42}(\mathrm{~A} \beta \mathrm{O} ; 1 \mu \mathrm{M})$ for $24 \mathrm{~h}$ and $48 \mathrm{~h}$. a The level of reactive oxygen species in cells was estimated by measuring fluorescence of DCF $(n=4)$. b $\Delta \Psi \mathrm{m}$ was analyzed by using fluorescent dye JC-1 with flow-cytometric detection $(n=6)$. c, d Cell viability was measured by MTT assay after 24 and $48 \mathrm{~h}(n=24)$. Data represent the mean value \pm S.E.M. Statistical analysis was performed by using Student's $t$ test $(\mathbf{a}, \mathbf{b})$ or one-way ANOVA with Bonferroni post hoc test (c, d). $* p<0.05 ; * * p<0.01 ; * * * p<$ 0.001 , as compared to the control group a

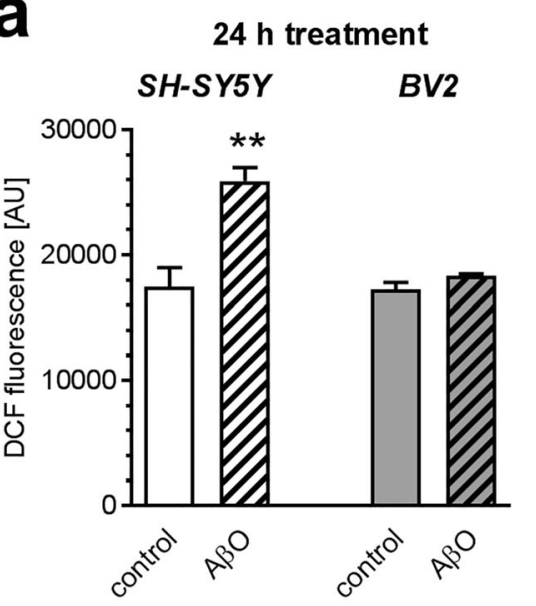

C

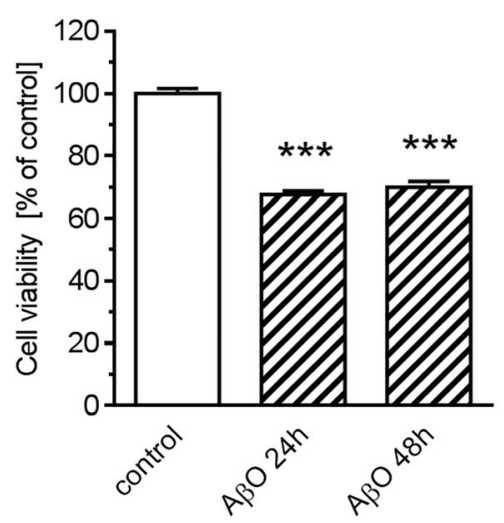

b
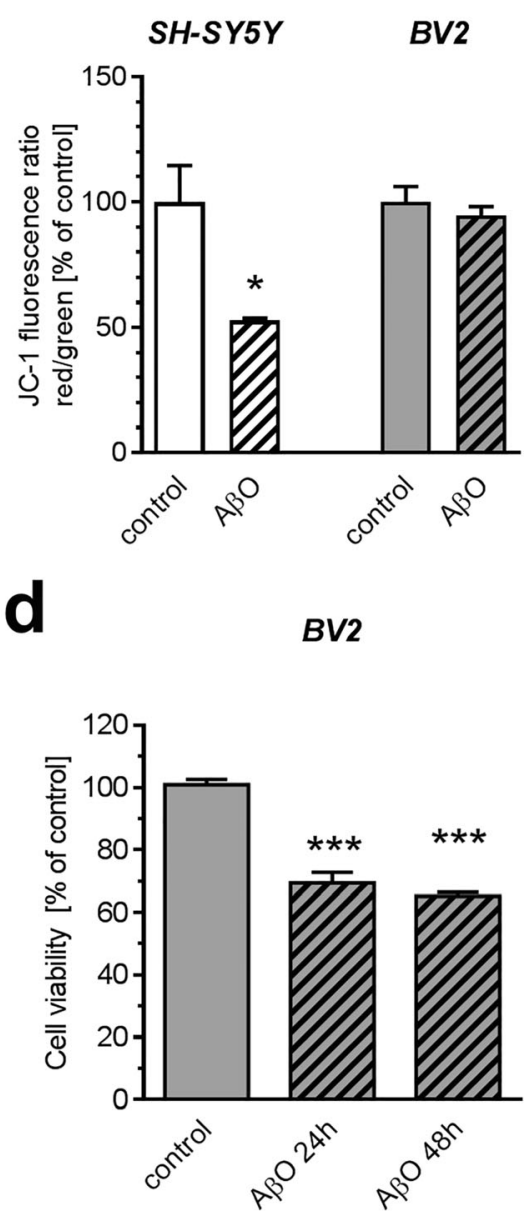

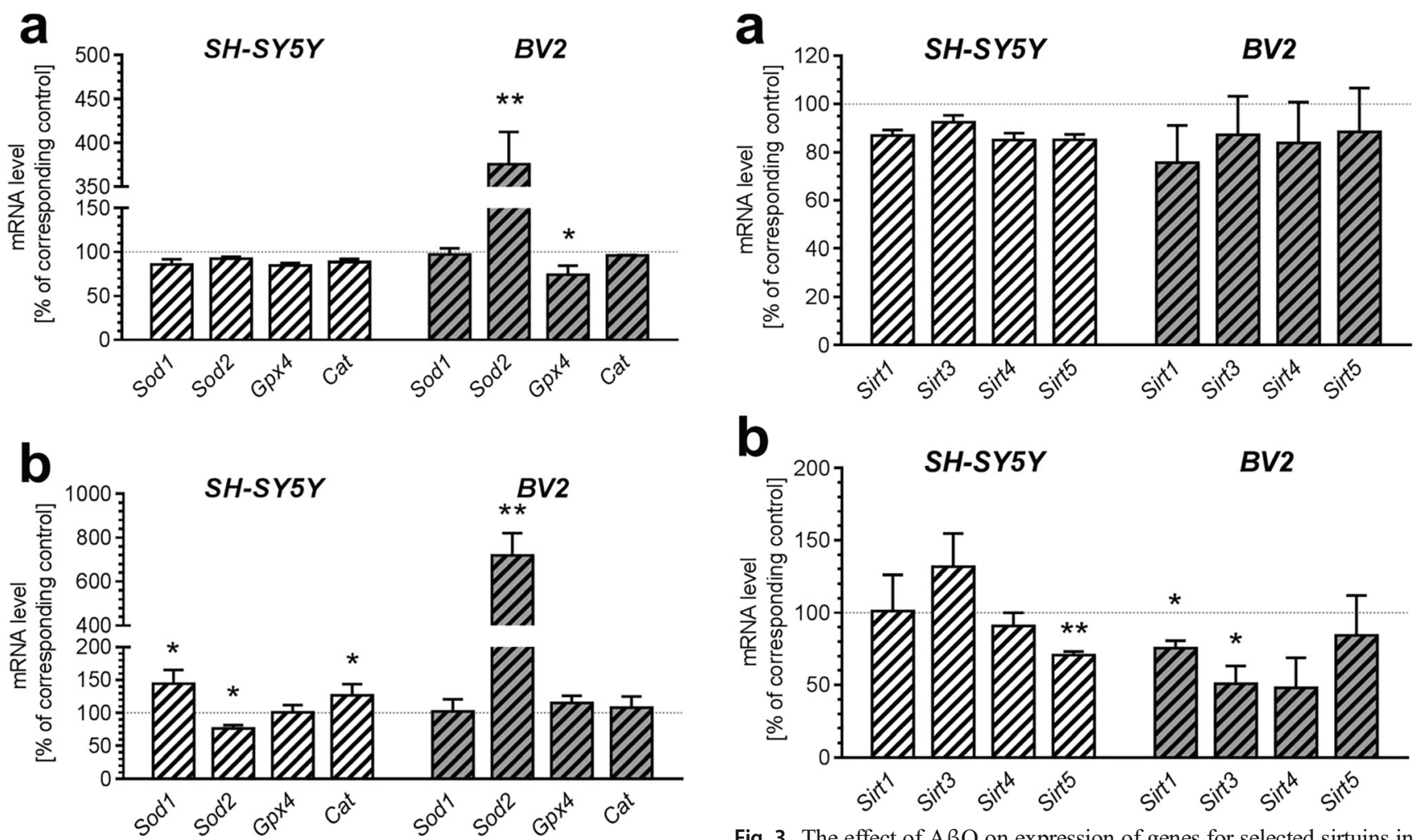

Fig. 2 The effect of $A \beta O$ on expression of genes for selected antioxidative enzymes in SH-SY5Y and BV2 cells. SH-SY5Y and BV2 cells were incubated in the presence of oligomeric $A \beta_{1-42}(A \beta O ; 1 \mu M)$ for $24 \mathrm{~h}$ (a) and $48 \mathrm{~h}(\mathbf{b})$. The levels of mRNA of superoxide dismutase 1 and 2 (Sod1 and Sod2), glutathione peroxidase $4(G p x 4)$ and catalase (Cat) were analyzed by quantitative RT-PCR. The results were normalized to $A c t b$ gene expression. Data represent the mean value \pm S.E.M. for $5-8$ independent experiments carried out in triplicate. Statistical analysis was performed by using Student's $t$ test. $* p<0.05 ; * p<0.01$, as compared to the respective control group

Also, transcription of genes for Sirt1 and mitochondrial sirtuins Sirt3, $-4,-5$ contrasted in SH-SY5Y and BV2 cells (Fig. 3). Whereas $24 \mathrm{~h}$ incubation in the presence of $\mathrm{A} \beta \mathrm{O}$ did not affect mRNA level of Sirt1, Sirt3, Sirt4 and Sirt5, prolonged $48 \mathrm{~h}$ incubation significantly influenced expression of these genes differently in neuronal and microglial cells. A $\beta O$ reduced expression of Sirt $1(p=0.0397)$ and Sirt3 $(p=0.0341)$ in BV2, and decreased Sirt5 $(p=0.003)$ in SH-SY5Y cells (Fig. 3b).

At the same time, a clear difference in expression of genes for mitochondrial electron transport chain (ETC) complexes was observed. After $24 \mathrm{~h}$ incubation, the level of mRNA for Sdha $(p=0.0345)$ and mitochondrially encoded $m t-N d 1$ ( $p=0.0423)$ was significantly decreased in BV2 line, but $m t-C y t b$ and $m t$ Col were not affected (Fig. 4a). Expression of Sdha ( $p$ $=0.0235)$ was slightly reduced in SH-SY5Y line, but other genes were not altered in this time-point. After prolonged $48 \mathrm{~h}$ incubation, reduced expression of $S d h a$ in BV2 was maintained $(p=0.0154)$ but change in $m t-N d 1$

was not statistically significant $(p=0.0556)$. Contrary, after $48 \mathrm{~h}$ treatment, mRNA level for $m t-N d 1$ in SH-SY5Y was elevated ( $p=0.0332$ ) (Fig. 4b). Activity of cytochrome $\mathrm{c}$ oxidase (complex IV) was three times higher in BV2 cells comparing to SH-SY5Y ( $p=0003)$; however, it was not affected by $\mathrm{A} \beta \mathrm{O}$ (Fig. 4c).

Moreover, to analyse mitochondrial dynamics, expression of genes related to fusion-fission was measured. Incubation in the presence of $\mathrm{A} \beta \mathrm{O}$ for $24 \mathrm{~h}$ reduced expression of Mfn2 exclusively in BV2 cells ( $p=$ 0.029 ) but other tested genes were not affected (Fig. 5a). After $48 \mathrm{~h}$ incubation, $\mathrm{A} \beta \mathrm{O}$ significantly enhanced mRNA level for Dnm1l ( $p=0.0407$ ) in BV2 cells (Fig. 5b). Similarly, to recognize cell type-dependent specific features of cell death mechanisms, we analysed the transcription of fundamental mitochondria-related supervisors of apoptosis-proapoptotic Bax and antiapoptotic Bcl2. Incubation in the presence of $\mathrm{A} \beta \mathrm{O}$ for up to $24 \mathrm{~h}$ had no impact on mRNA level for Bax and Bcl2 in SH-SY5Y line. However, in BV2 line, expression of the Bax gene was 
a

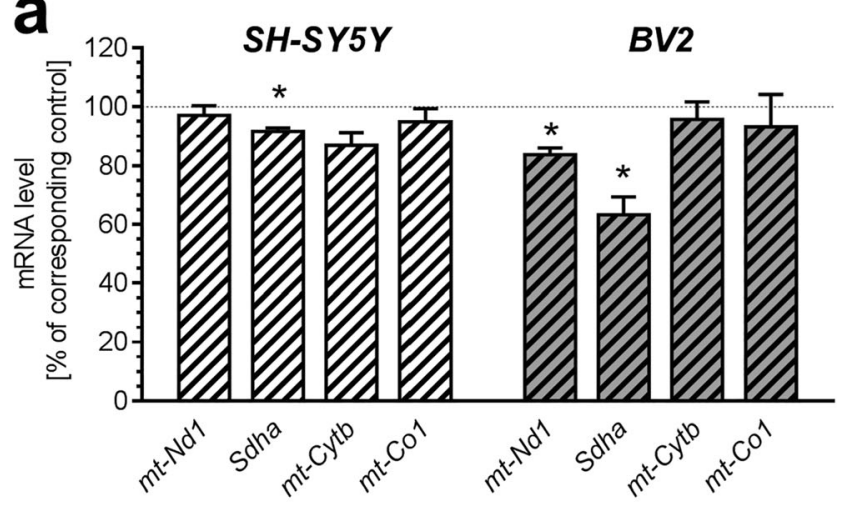

b
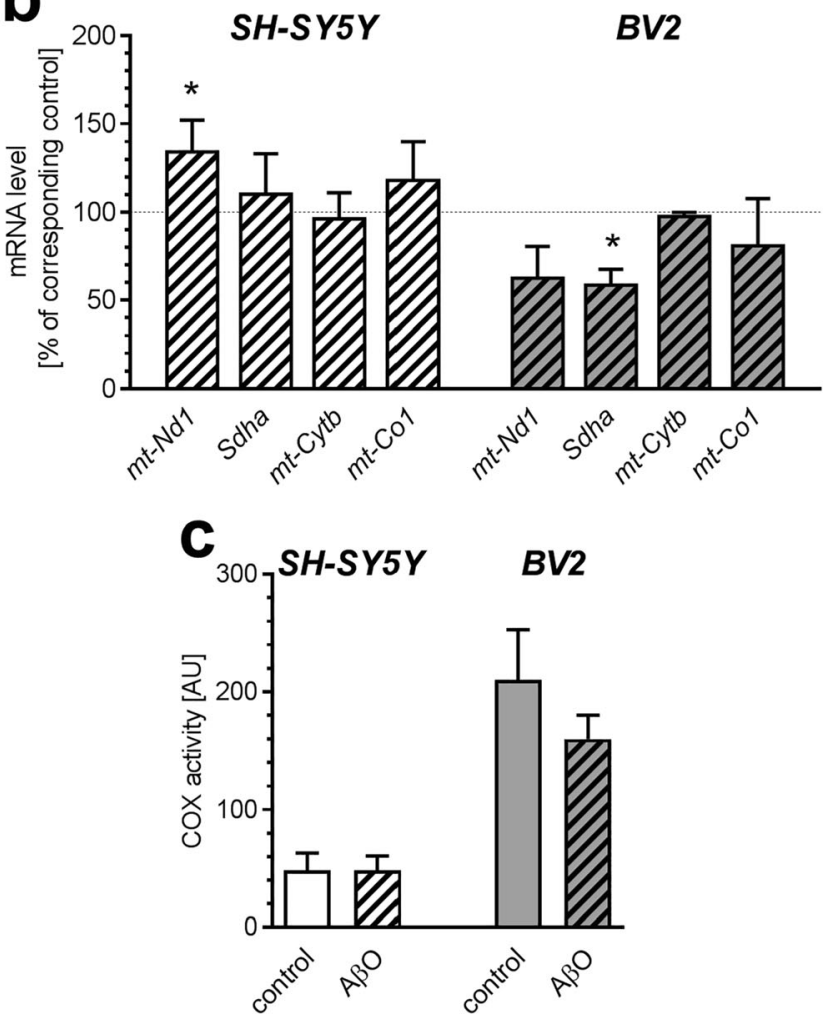

Fig. 4 The effect of $\mathrm{A} \beta \mathrm{O}$ on expression of genes for selected subunits of electron transport chain and cytochrome c oxidase activity in SH-SY5Y and BV2 cells. SH-SY5Y and BV2 cells were incubated in the presence of oligomeric $\mathrm{A} \beta_{1-42}(\mathrm{~A} \beta \mathrm{O} ; 1 \mu \mathrm{M})$ for $24 \mathrm{~h}(\mathbf{a})$ and $48 \mathrm{~h}(\mathbf{b})$. The levels of mRNA of mitochondrially encoded NADH dehydrogenase 1 ( $m t-N d 1)$, succinate dehydrogenase complex, subunit A flavoprotein (Sdha), mitochondrially encoded cytochrome $\mathrm{b}(m t-C y t b)$ and mitochondrially encoded cytochrome c oxidase I ( $m t-\mathrm{Col}$ ) were analyzed by quantitative RT-PCR. The results of RT-PCR were normalized to Actb gene expression. $\mathbf{c}$ SH-SY5Y and BV2 cells were incubated in the presence of oligomeric $\mathrm{A} \beta_{1-42}(\mathrm{~A} \beta \mathrm{O} ; 1 \mu \mathrm{M})$ for $24 \mathrm{~h}$. Activity of COX was estimated as described in "Materials and Methods". Data represent the mean value \pm S.E.M. for 4-6 independent experiments carried out in triplicate. Statistical analysis was performed by using Student's $t$ test. ${ }^{*} p<$ 0.05 , as compared to the respective control group

significantly reduced $(p=0.0242)$ and the mRNA level for $B c l 2$ was not altered. In condition of prolonged $48 \mathrm{~h}$ incubation with $\mathrm{A} \beta \mathrm{O}$, expression of $B c l 2$ was significantly increased
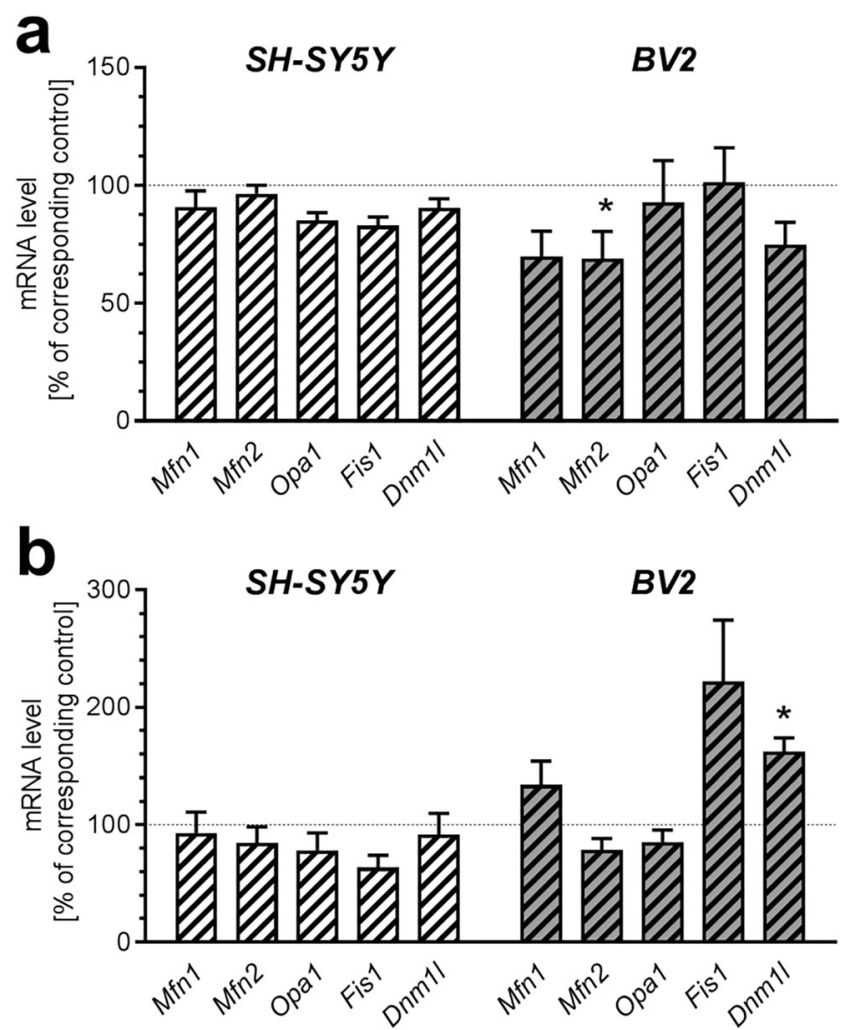

Fig. 5 The effect of $\mathrm{A} \beta \mathrm{O}$ on expression of genes for proteins involved in mitochondrial fission-fusion in SH-SY5Y and BV2 cells. SH-SY5Y and BV2 cells were incubated in the presence of oligomeric $A \beta_{1-42}(\mathrm{~A} \beta \mathrm{O} ; 1$ $\mu \mathrm{M})$ for $24 \mathrm{~h}(\mathbf{a})$ and $48 \mathrm{~h}(\mathbf{b})$. The levels of mRNA of mitofusin 1 and 2 (Mfn1 and Mfn2), optic atrophy 1 (Opal), fission mitochondrial 1 (Fis 1), dynamin 1-like, also known as DRP1 (Dnmll) were analyzed by quantitative RT-PCR. The results of RT-PCR were normalized to Actb gene expression. Data represent the mean value \pm S.E.M. for 5-6 independent experiments carried out in triplicate. Statistical analysis was performed by using Student's $t$ test. $* p<0.05$, as compared to the respective control group

in both cells lines ( $p=0.0219$ in SH-SY5Y and $p=0.0317$ in BV2), but the increase in BV2 line seems to be more substantial. The mRNA level for Bax was not changed (Fig. 6).

\section{Effect of Pharmacological Modulation of NAD ${ }^{+}$-Dependent Enzymes on Viability of BV2 and SH-SY5Y Cells}

In our study, we compared the role of $\mathrm{NAD}^{+}$-dependent enzymes, poly(ADP-ribose) polymerase-1 (PARP1) and sirtuins, in molecular mechanism of $\mathrm{A} \beta$ toxicity in $\mathrm{SH}-$ SY5Y and BV2 lines (Fig. 7). Co-incubation with PARP1 inhibitor, Olaparib, partially protected both SH-SY5Y ( $p=$ 0.0214 after $24 \mathrm{~h}$ and $p=0.0191$ after $48 \mathrm{~h})$ and BV2 ( $p=$ 0.0081 after $24 \mathrm{~h}$ ) cells against $\mathrm{A} \beta \mathrm{O}$-evoked toxicity $(p<$ 0.0001). Co-incubation with Sirt activator, SRT1720, reduced A $\beta$-triggered toxicity in SH-SY5Y $(p<0.0001$ after $24 \mathrm{~h}$ and after $48 \mathrm{~h}$ ), but had no effect in BV2 cells. 
a

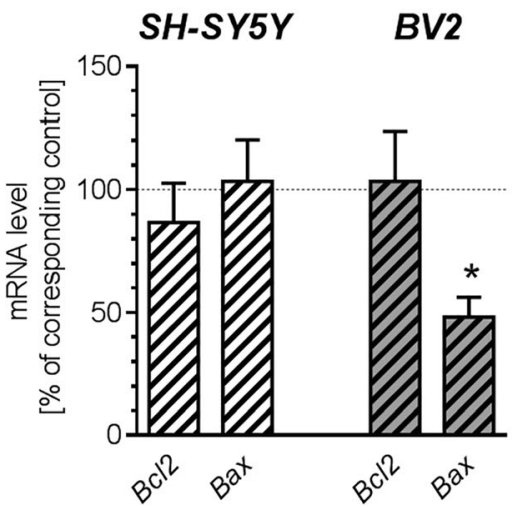

Fig. 6 The effect of $\mathrm{A} \beta \mathrm{O}$ on expression of genes for apoptosis-related proteins in SH-SY5Y and BV2 cells. SH-SY5Y and BV2 cells were incubated in the presence of oligomeric $\mathrm{A} \beta_{1-42}(\mathrm{~A} \beta \mathrm{O} ; 1 \mu \mathrm{M})$ for $24 \mathrm{~h}$ (a) and $48 \mathrm{~h}$ (b). The levels of mRNA for $B c l 2$ and $B a x$ were analyzed by quantitative RT-PCR. The results of RT-PCR were normalized to Actb b

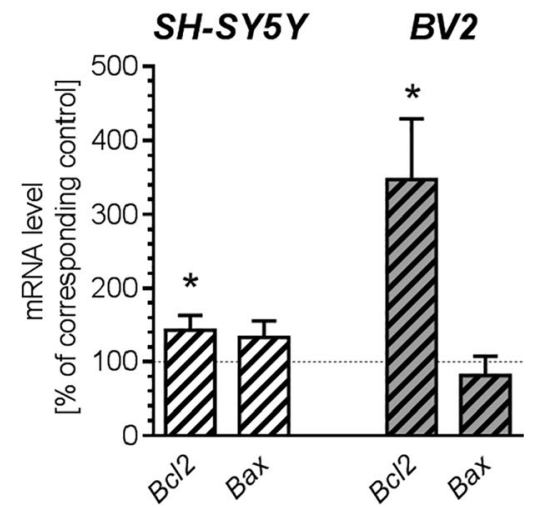

gene expression. Data represent the mean value \pm S.E.M. for $5-7$ independent experiments carried out in triplicate. Statistical analysis was performed by using Student's $t$ test. $* p<0.05$, as compared to the respective control group
Fig. 7 The effect of pharmacologically active compounds on $\mathrm{A} \beta \mathrm{O}-$-evoked reduction of SH-SY5Y and BV2 cell viability. SH-SY5Y and BV2 cells were incubated for 24 (a, c) and $48 \mathrm{~h}(\mathbf{b}, \mathbf{d})$ in the presence of oligomeric $\mathrm{A} \beta(\mathrm{A} \beta \mathrm{O} ; 1 \mu \mathrm{M})$ and various pharmacologically active compounds: Olaparib $(3.3 \mu \mathrm{M})$ and SRT1720 $(0.1 \mu \mathrm{M})$. Cell viability was determined by using MTT assay, as described in "Materials and Methods". Data represent the mean value \pm

S.E.M. for six $(\mathrm{A} \beta \mathrm{O}+$ Olaparib and $\mathrm{A} \beta \mathrm{O}+\mathrm{SRT} 1720)$ to 24

$(\mathrm{A} \beta \mathrm{O})$ independent experiments. $* * * p<0.001$, as compared to the control cells, $\# p<0.05 ; \# \# p<$ 0.01 ; \#\#\#p<0.001, as compared to $\mathrm{A} \beta \mathrm{O}$-treated group, by using a one-way ANOVA followed by Bonferroni post hoc test a

SH-SY5Y

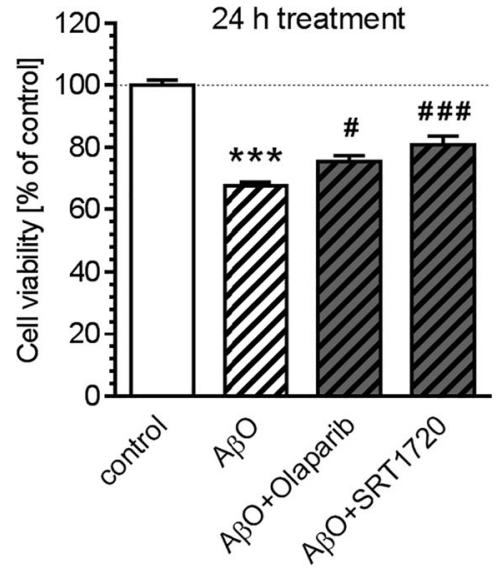

C

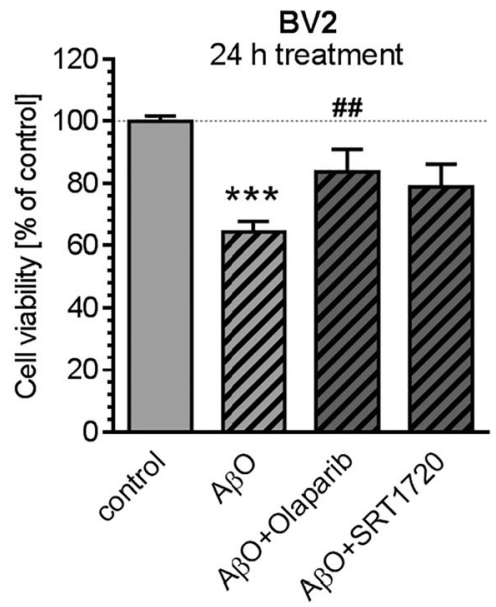

b

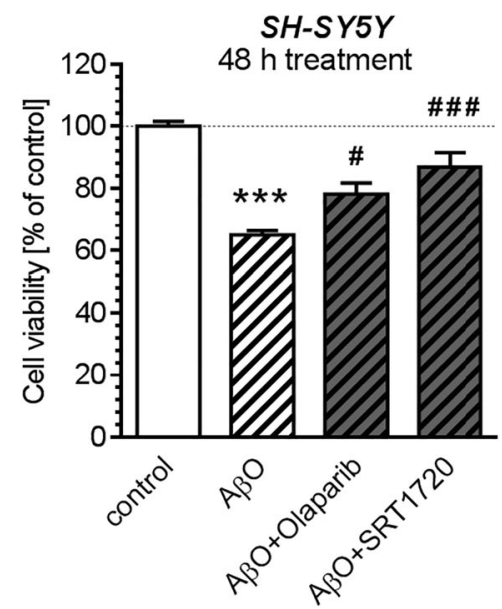

d

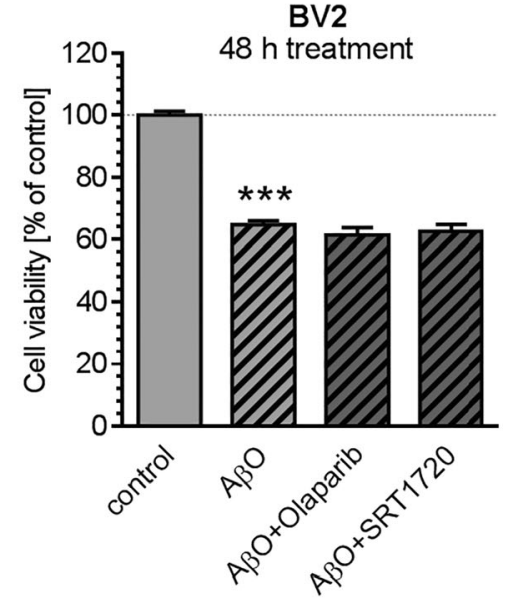




\section{Alterations of Expression of Genes for Proteins Related to Antioxidative Defence and Mitochondrial Function in Brain Cortex of Mouse Model of AD}

To assess whether analogous changes in gene expression induced by $\mathrm{A} \beta$ occur in vivo, we analysed mRNA levels in animal model of Alzheimer's disease. As shown in Fig. 8, in 12-month-old $\mathrm{APP}^{+}$mice, which stably overexpress human $A P P$ gene with London mutation, mRNA levels for several mitochondria-related genes in brain cortex are altered, comparing to control animals. As shown in Fig. 8a, the levels of mRNA for antioxidative enzymes (Sod1, Sod2, Gpx4, Cat) were not changed in $\mathrm{APP}^{+}$mice, comparing to control $\mathrm{APP}^{-}$. Among tested sirtuins, only expression of Sirt1 was reduced (Fig. 8b; $p=0.0383$ ); expression of other sirtuins was not affected. Analysis of mRNA for complexes of mitochondrial electron transport chain (Fig. 8c) revealed slight decrease in the level of mRNA for mitochondrially encoded $m t-N d 1$ ( $p=0.0138$ ), but changes of other tested genes were not statistically significant. The last group tested in mouse model of $\mathrm{AD}$ were genes for proteins involved in mitochondrial dynamics (Fig. 8d). It was found that mRNA level for $M f n 1$ that is responsible for mitochondrial fusion was reduced ( $p=0.0111)$, whereas expression of Dnmll that regulates mitochondrial fission was significantly increased $(p=0.0019)$. The level of mRNA for other tested genes was not changed.

\section{Alterations of Expression of miRNA Related to Post-Transcriptional Regulating of Sirt1 Gene in Brain Cortex of AD Patients}

Then, our further study on short post-mortem interval (PMI) human brain tissues using array-based miRNA-mRNA analysis and miRNA-mRNA-based linking assay showed a significant upregulation of miRNA-9, miRNA-34a, miRNA146a and miRNA-155 in AD brain compared to age-, gender- and (PMI-matched) controls [49, 50]. Remarkably, each of these pro-inflammatory microRNAs has a binding site in the SIRT1 mRNA 3'untranslated region (3'UTR) (Fig. 9).

\section{Discussion}

It is widely accepted that $A \beta$-evoked oxidative stress plays crucial role in pathomechanism of AD. Moreover, it was also shown that microglia activation and mitochondria dysfunction may enhance production of reactive oxygen species (ROS) which subsequently could contribute to the progression of AD. In our study, we have investigated how $A \beta$ oligomers influence expression of selected genes related to antioxidative defence and to mitochondrial function in microglial BV2 and in neuronal SH-SY5Y cells in culture. Our data indicated that $\mathrm{A} \beta \mathrm{O}$ significantly affected viability of both types of cells;
Fig. 8 The effect of expression of human $A P P$ gene in mice on mRNA levels for mitochondriarelated genes in brain cortex. Expression of genes in brain cortex of 12 month old male mice, $\mathrm{APP}^{-}$and $\mathrm{APP}^{+}$was analysed by quantitative RT-PCR. The results of RT-PCR were normalized to $A c t b$ gene expression. Data represent the mean value \pm S.E.M. for three animals in each group. Statistical analysis was performed by using Student's $t$ test. * $p<$ $0.05 ; * * p<0.01$, as compared to the respective control group a

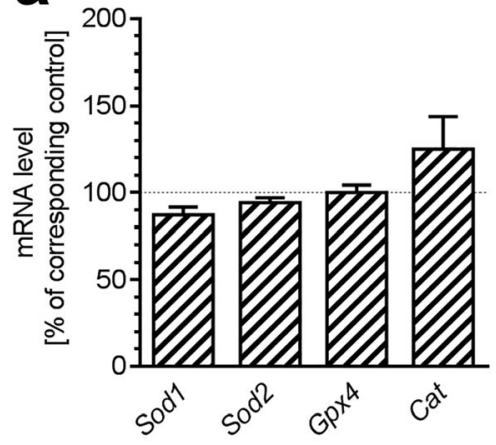

b
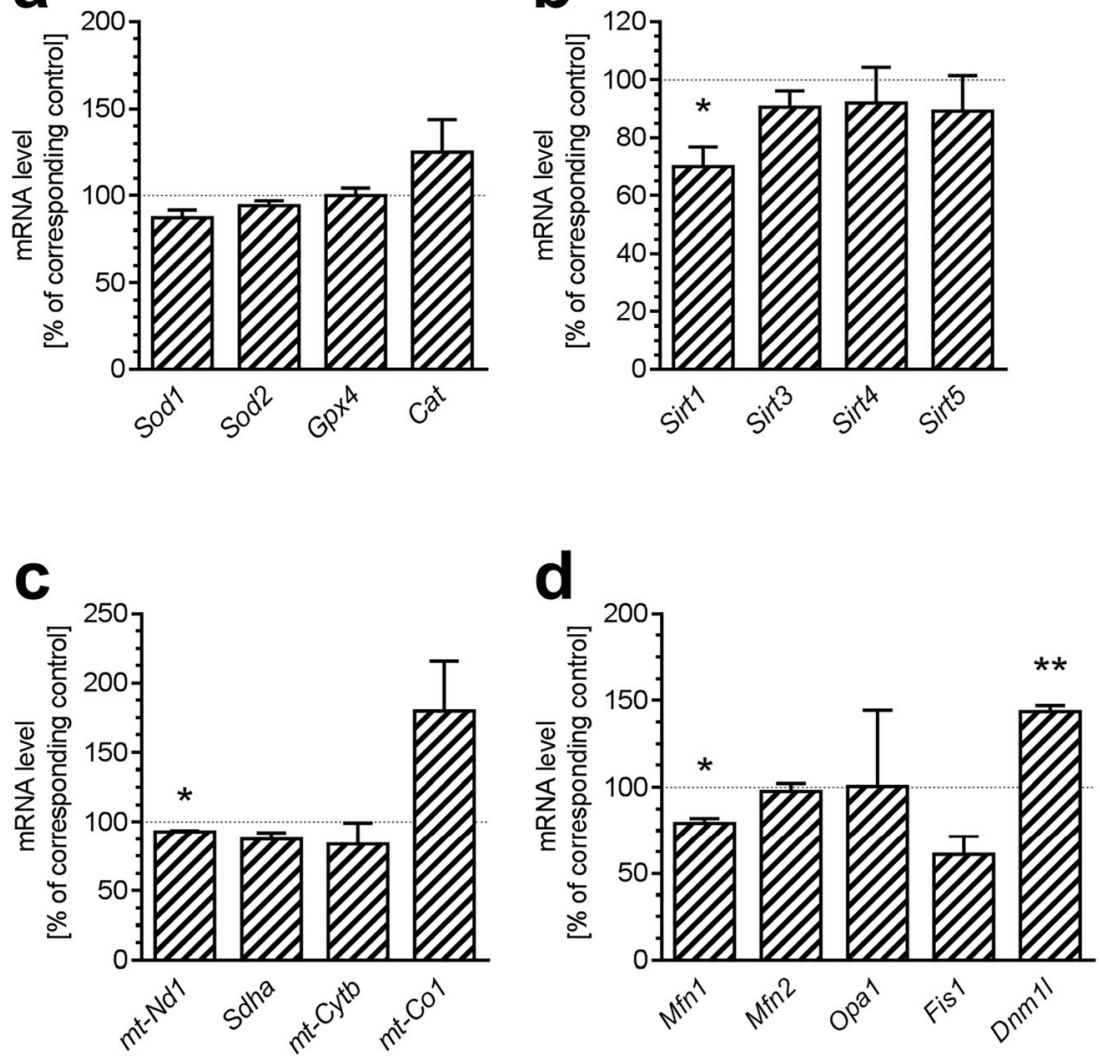

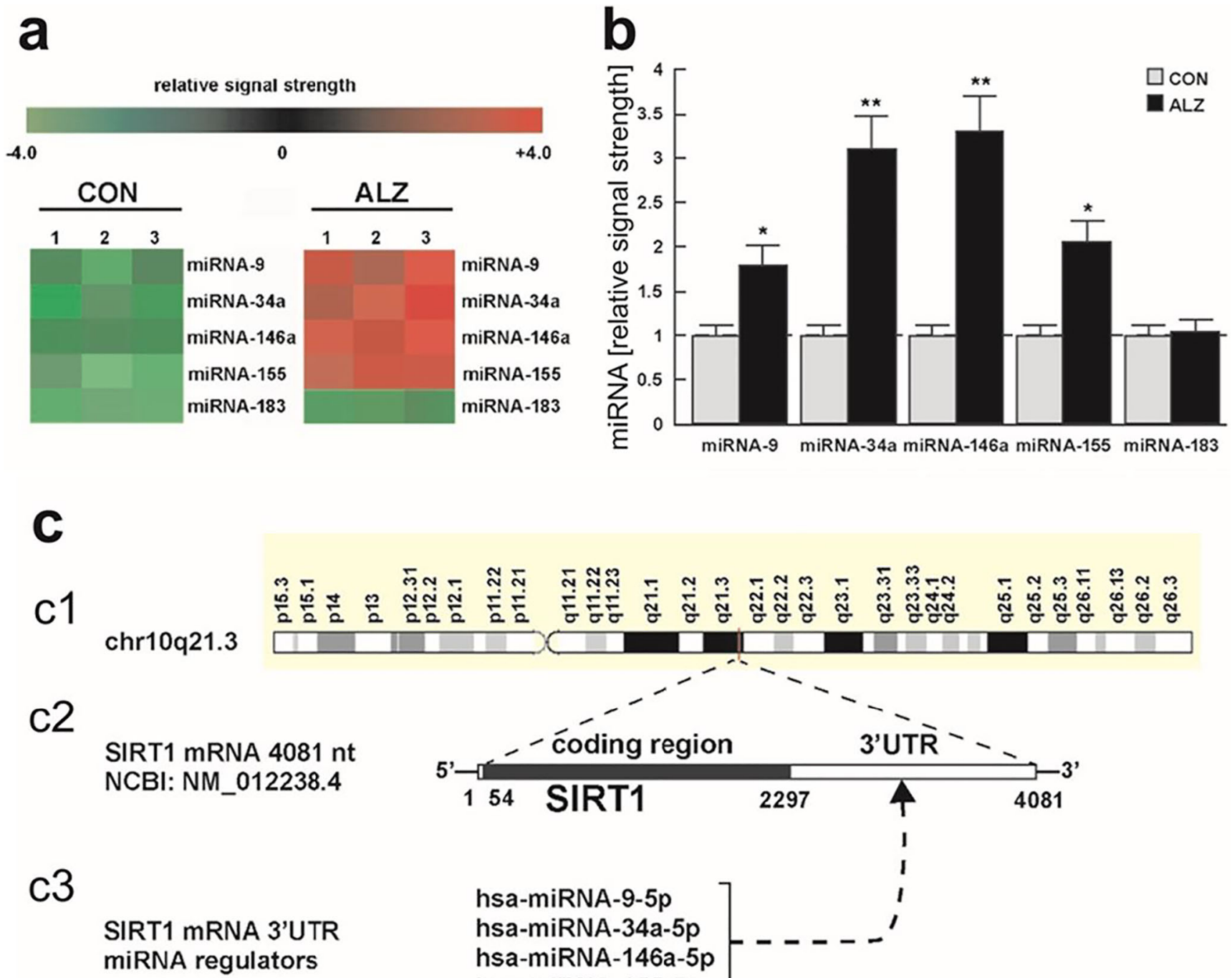

Fig. 9 miRNA-upregulation and SIRT1 downregulation in AD brain. Brain samples from temporal cortex of AD brains and age-matched controls (all female) were used for isolation of miRNA. Analysis of miRNA was performed, as described above. The results of a miRNA-array based analysis of three controls versus three AD brains presented in cluster diagram 'heat map' format (a) and in bar graph format (b). Compared to age-, gender- and post-mortem interval-matched controls, miRNA-9, miRNA-34a, miRNA-146a and miRNA-155 are significantly

however, differently altered expression of genes encoding crucial antioxidative enzymes SOD1 and SOD2. The expression of gene for mitochondrial SOD2 (Sod2) was about seven times higher after $48 \mathrm{~h}$ of $\mathrm{A} \beta \mathrm{O}$ treatment in BV2 cells, but the expression of gene for this enzyme in neuronal cells was significantly inhibited. However, Sodl transcription together with catalase (Cat) was enhanced by about $20-40 \%$ in neuronal SH-SY5Y cells. The significant differences were observed also in gene expression of sirtuins, as for example SIRT1 and SIRT3, which are involved in antioxidative defence [52]. In microglia BV2 cells, transcription of Sirt1 and Sirt3 was decreased, but in neuronal SH-SY5Y cells, only the gene expression for Sirt5 was downregulated. These differences may play an important role in oxidative stress evoked by $\mathrm{A} \beta \mathrm{O}$ in these two cells lines. It is also known that neurons are most vulnerable cells for oxidative injures, while microglia and astrocytes are much more resistant [53]. Oxidative damage is one of the earliest and the most important events in $\mathrm{AD}$ [54-58]. A $\beta$ oligomers enhance free radical levels, and alter the balance between pro-oxidative and antioxidative processes leading to alterations of pro-survival kinases and several signalling pathways, neuronal impairment and synaptic degeneration which were indicated by many studies, including our recent data $[15,45,46,59]$. 
Alteration of function of mitochondrial ETC complexes may be responsible for the enhancement of ROS production and energy alteration. The present study demonstrates that $A \beta_{1-42}$ oligomers significantly affected the level of free radicals in neuronal cells SH-SY5Y but had no effect on the level of ROS in microglial BV2 cells. It seems that higher expression of SOD2 in BV2 cells may protect against free radicals' accumulation and, in consequence, against their deleterious influences on macromolecules and mitochondrial function $[15,58]$. However, until now, the role of $\mathrm{A} \beta \mathrm{O}$ in modulation of gene expression related to oxidative stress and mitochondria function in microglia and in neuronal cells is not fully elucidated.

Our data indicated the lower expression of subunits of complex I and II of ETC in A $\beta O$-treated microglial BV2 cells. The significant alterations were observed after short-time incubation $(24 \mathrm{~h})$. These changes may indicate transient downregulation of microglial ETC function because after $48 \mathrm{~h}$ of A $\beta \mathrm{O}$ treatment, only gene expression for subunit of complex II (Sdha) was decreased. Activation of gene expression for Sod2 in BV2 cells may suggest that it is a part of mechanism protecting mitochondria against ROS generated by impaired ETC in conditions of A $\beta O$ toxicity. Analysis of gene expression of subunits of ETC in SH-SY5Y cells indicated lower level of mRNA for subunit of complex II ( $S d h a$ ) after $24 \mathrm{~h}$ of $\mathrm{A} \beta \mathrm{O}$ treatment and enhancement of subunit of complex I after $48 \mathrm{~h}$. The activity of cytochrome c oxidase in BV2 cells was three times higher, comparing to activity of this enzyme in SH-SY5Y cells. Previous data showed that complex IV is affected in $\mathrm{AD}$ brain. It was demonstrated that cytochrome $\mathrm{c}$ oxidase (COX) activity is significantly decreased in the brains of AD patients, comparing to healthy controls [60, 61]. However, in vitro studies showed that the inhibitory effect of $\mathrm{A} \beta_{1-42}$ on COX activity is dependent on the presence of $\mathrm{Cu}^{2+}$ ions $[62,63]$. This effect seems to be specific for copper ions, because it was not observed in the presence of $\mathrm{Fe}^{2+}, \mathrm{Fe}^{3+}$ or $\mathrm{Zn}^{2+}$. Copper-dependent inhibition of COX by $\mathrm{A} \beta_{1-42}$ requires reduced methionine-35 and seems to be dependent on the $A \beta$ 's capacity to bind and reduce $\mathrm{Cu}^{2+}$.

The significantly higher Sod 2 expression and higher COX activity in microglial BV2 comparing to neuronal SH-SY5Y cells could be responsible for significant differences in maintaining mitochondria membrane potential $(\Delta \Psi \mathrm{m})$ in condition of $\mathrm{A} \beta \mathrm{O}$ toxicity. Our results suggest that mitochondrial function and ATP production is preserved in BV2 cells, opposite to SH-SY5Y cells. Additionally, the significantly higher expression of Bcl2 in BV2 comparing to SH-SY5Y cells may also have a positive effect on mitochondrial membrane integrity. $\Delta \Psi \mathrm{m}$ in BV2 cells was not altered after $24 \mathrm{~h}$ of $\mathrm{A} \beta \mathrm{O}$ treatment, comparing to control conditions. On the other hand, the level of free radicals was increased and $\Delta \Psi \mathrm{m}$ was significantly decreased in SH-SY5Y cells by A $\beta$ toxicity. The results indicate that $\mathrm{A} \beta \mathrm{O}$ exerts toxic effect on SH-SY5Y cells, but in BV2 cells it activates several defensive mechanisms which could contribute to neuroprotective function of microglial cell in early stage of $\mathrm{A} \beta \mathrm{O}$ toxicity.

It was previously demonstrated that SOD2 and other SODs play a critical role in inactivation of superoxide radicals and nitric oxide, preventing peroxynitrite formation and mitochondria dysfunction, which may lead to the extension of lifespan of flies and mice [64, 65]. Our results may suggest that SOD2 in microglia could be responsible for higher resistance of these cells to oxidative stress evoked by $\mathrm{A} \beta$, comparing to neuronal cells. However, viability of both cells types is significantly affected by $A \beta$ toxicity suggesting that different mechanisms could be responsible in regulation of these cells survival/death pathway. Activator of sirtuins, SRT1720, which particularly activates Sirt1, enhanced neuronal SHSY5Y cell viability suppressed by $\mathrm{A} \beta \mathrm{O}$. However, in microglial cells, SRT1720 had no significant effect. In this study, inhibitor of poly(ADP-ribose)polymerase-1 (PARP-1) Olaparib exerted also cytoprotective action on neuronal cells under $\mathrm{A} \beta \mathrm{O}$ toxicity and enhanced BV2 viability transiently after $24 \mathrm{~h}$. These differences may be connected with significant downregulation of transcription of Sirt1 and Sirt 3 in BV2 cells and probably with lower activity of these enzymes [23].

Sirtuins and poly(ADP-ribose)polymerases (PARPs) use $\beta$ $\mathrm{NAD}^{+}$as a substrate, and it was proposed that inhibitors of PARPs are the most effective activators of Sirts [66]. The best characterized mammalian sirtuin is Sirt1. A lot of studies were carried out also on the role of Sirt3 in mitochondria, aging and neurodegeneration [23, 67]. These both Sirts control mitochondria function and antioxidative enzymes through deacetylation of several targets including SOD2, GPX, PGC1 $\alpha$, unfolding protein responses (UPR), FOXO signalling [23, 26, 27]. The NAD/sirtuin pathway influences lifespan, and it is suggested that activation of Sirts, with one exception of Sirt2, may protect the brain against neurodegeneration [27, 68-71]. However, a lot of questions in this field must be solved as indicated by Dang [72]. The data of Ekblad and Schuler [73] suggested that sirtuins are not affected by PARP inhibitors (including PJ34 and Olaparib). Our recently published data indicated that PARP inhibition enhanced significantly expression of Sirt1 and Sirt6 in the absence and in the presence of $\mathrm{A} \beta \mathrm{O}$ and enhanced transcription of mitochondrial Sirt4 [74].

In this study, activator of sirtuins (mainly Sirt1) SRT1720 and PARP1 inhibitor Olaparib considerably enhanced neuronal cell viability which was significantly decreased by $\mathrm{A} \beta \mathrm{O}$ toxicity and had also protective effect on microglia viability after short time $24 \mathrm{~h}$ of $\mathrm{A} \beta \mathrm{O}$ treatment. Our previous data showed that PARP1 inhibitor activated expression of several mitochondria-related genes in $\mathrm{PC} 12$ cells in control conditions and $\mathrm{A} \beta \mathrm{O}$ toxicity. Concomitantly, $\mathrm{A} \beta \mathrm{O}$ exerted significant time-dependent inhibitory effect on expression of genes encoding several proteins involved in regulation of mitochondrial dynamics and subunits of oxidative complexes [45]. 
Our research carried out on Tg-AD murine models indicated significant downregulation of gene transcription of Sirt1, which plays a crucial role in APP metabolism through the regulation of secretase alpha [27, 74]. Moreover, our study indicated the lower transcription of gene Mnfl and higher expression of gene encoding Drp1, the crucial protein for mitochondrial dynamics. Recent studies demonstrated abnormalities of mitochondria in AD evoked by altered homeostasis in transcription of genes for highly conserved proteins with GTP-ase activity which are responsible for changes of mitochondria fragmentation and fusion $[21,36,44,75,76]$.
Manczak and colleagues indicated that partial reduction of Drp1 diminishes mitochondria dysfunction, maintains mitochondrial dynamics and enhances mitochondrial biogenesis and synaptic activity in $\mathrm{APP}^{+}$mice. Decrease of the level of Drp 1 may reduce production of $A \beta$ and, in consequence, maintain axonal transport of mitochondria and supplying the sufficient quantities of ATP in AD neurons [44]. The expression and function of mitochondrial and synaptic proteins is significantly regulated by complex molecular processes including miRNA. It has been demonstrated that miRNA through post-transcriptional alteration may affect neuronal

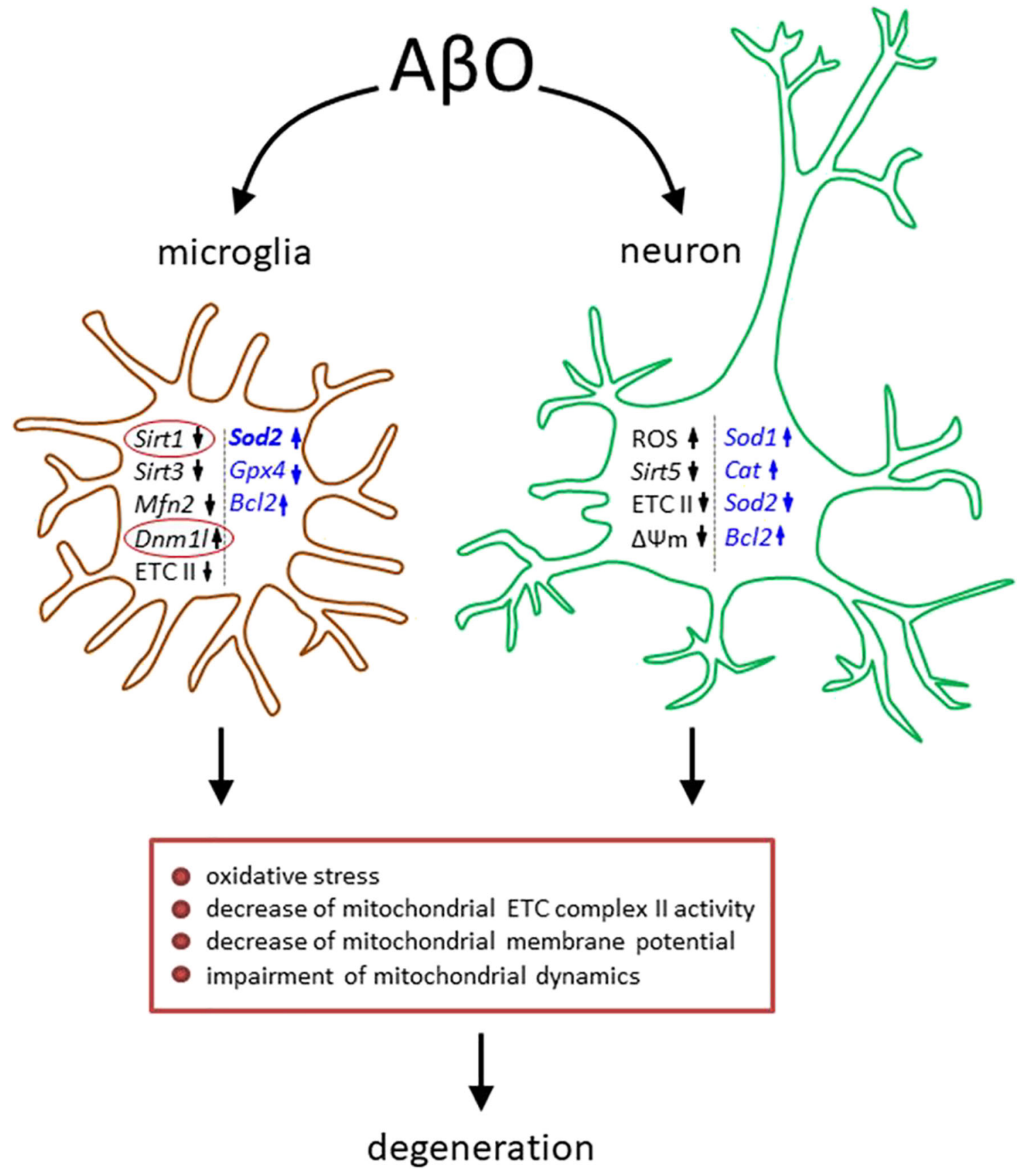

Fig. 10 Schematic representation of main findings of the study 
circuit development, maturation and function [77, 78]. Recent studies demonstrated a crucial role of miRNA in the pathomechanism of neurodevelopmental and neurodegenerative disorders (including AD). It is now well known that upregulated miRNAs predominantly act to decrease target mRNA levels via miRNA-mRNA-coupled signalling networks [49, 79]. Our finding demonstrated that brainabundant miRNAs including miRNA-9, miRNA-34a, miRNA-146a and miRNA-155 are upregulated and target the SIRT1 mRNA 3'UTR. These data may explain why SIRT1 expression is found to be downregulated in AD. AntimiRNA-based therapeutic strategies may be useful to normalize miRNA-9, miRNA-34a, miRNA-146a and/or miRNA155 levels and restore homeostasis in $\mathrm{AD}$ or in brain pathologies where $A \beta O$ is over-abundant.

\section{Conclusions}

In summary, our study indicated the significant impact of $A \beta$ oligomers on expression of several genes related to antioxidative defence and mitochondrial function and dynamics in neuronal and microglial cells and in the brain cortex of Tg-AD mice (Fig. 10). The most important finding of this study is downregulation of Sirt1 gene in glia cells and in brain cortex of $\mathrm{AD}$ mice and high transcription of gene encoding DRP1, the key protein in mitochondria fragmentation. The overexpression of specific miRNAs in human AD brain may explain, in part, the downregulation of SIRT1 that is crucial player in homeostatic mitochondrial operation, APP metabolism and the maintenance of redox state. On the basis of these data, we suggest that modulation of expression and/or activity of Mfn1, Drp1 and Sirt1, including anti-miRNA-based strategies, may be promising in the advancement of AD therapy.

Funding Information This work was supported by Statute Theme No 5 (Figs. 1, 2, 3 and 6 and 7), and by Grant NCN-2014/2015/B/NZ3/01049 (Figs. 4, 5, and 8). The result presented on Fig. 9 was supported through an unrestricted grant to the LSU Eye Center from Research to Prevent Blindness (RPB); the Louisiana Biotechnology Research Network (LBRN) and NIH grants NEI EY006311, NIA AG18031 and NIA AG038834 (WJL)

Compliance with Ethical Standards All applicable international, national and/or institutional guidelines for the care and use of animals were followed. The protocol was approved by the Warsaw Local Ethics Committee for Animal Experimentation.

Post-mortem human neocortical tissues were handled in strict accordance with the ethics review board policies at donor institutions, and the Institutional Biosafety Committee/Institutional Review Board (IBC/IRB) Committee's ethical guidelines (IBC no. 12323; IRB no. 6774) at the Louisiana State University Health Sciences Centre, School of Medicine, New Orleans LA 70112 USA.

Conflict of Interest The authors declare that they have no conflict of interest.
Open Access This article is distributed under the terms of the Creative Commons Attribution 4.0 International License (http:// creativecommons.org/licenses/by/4.0/), which permits unrestricted use, distribution, and reproduction in any medium, provided you give appropriate credit to the original author(s) and the source, provide a link to the Creative Commons license, and indicate if changes were made.

\section{References}

1. Hardy J, Allsop D (1991) Amyloid deposition as the central event in the aetiology of Alzheimer's disease. Trends Pharmacol Sci 12:383-388

2. Lesne S, Koh MT, Kotilinek L, Kayed R, Glabe CG, Yang A, Gallagher M, Ashe KH (2006) A specific amyloid-beta protein assembly in the brain impairs memory. Nature 440:352-357. https://doi.org/10.1038/nature04533

3. Selkoe DJ, Hardy J (2016) The amyloid hypothesis of Alzheimer's disease at 25 years. EMBO Mol Med 8:595-608. https://doi.org/10. 15252/emmm.201606210

4. Watson D, Castano E, Kokjohn TA et al (2005) Physicochemical characteristics of soluble oligomeric Abeta and their pathologic role in Alzheimer's disease. Neurol Res 27:869-881. https://doi.org/10.1179/016164105x49436

5. Lesne SE, Sherman MA, Grant M, Kuskowski M, Schneider JA, Bennett DA, Ashe KH (2013) Brain amyloid-beta oligomers in ageing and Alzheimer's disease. Brain 136:1383-1398. https://doi.org/10.1093/brain/awt062

6. Heppner FL, Ransohoff RM, Becher B (2015) Immune attack: the role of inflammation in Alzheimer disease. Nat Rev Neurosci 16: 358-372. https://doi.org/10.1038/nrn3880

7. Holmes C, Cunningham C, Zotova E, Woolford J, Dean C, Kerr S, Culliford D, Perry VH (2009) Systemic inflammation and disease progression in Alzheimer disease. Neurology 73:768-774. https:// doi.org/10.1212/WNL.0b013e3181b6bb95

8. Lichtenstein MP, Carriba P, Masgrau R, Pujol A, Galea E (2010) Staging anti-inflammatory therapy in Alzheimer's disease. Front Aging Neurosci 2:142. https://doi.org/10.3389/fnagi.2010.00142

9. Small GW, Siddarth P, Silverman DH, Ercoli LM, Miller KJ, Lavretsky H, Bookheimer SY, Huang SC et al (2008) Cognitive and cerebral metabolic effects of celecoxib versus placebo in people with age-related memory loss: randomized controlled study. Am J Geriatr Psychiatry 16:999-1009. https://doi.org/10.1097/JGP. 0b013e31818cd3a4

10. Mandrekar-Colucci S, Landreth GE (2010) Microglia and inflammation in Alzheimer's disease. CNS Neurol Disord Drug Targets 9:156-167

11. Hellwig S, Masuch A, Nestel S, Katzmarski N, Meyer-Luehmann M, Biber K (2015) Forebrain microglia from wild-type but not adult $5 \mathrm{xFAD}$ mice prevent amyloid-beta plaque formation in organotypic hippocampal slice cultures. Sci Rep 5:14624. https://doi.org/10. 1038/srep14624

12. Spangenberg EE, Lee RJ, Najafi AR, Rice RA, Elmore MR, Blurton-Jones M, West BL, Green KN (2016) Eliminating microglia in Alzheimer's mice prevents neuronal loss without modulating amyloid-beta pathology. Brain 139:1265-1281. https://doi.org/10. 1093/brain/aww016

13. Spangenberg EE, Green KN (2017) Inflammation in Alzheimer's disease: lessons learned from microglia-depletion models. Brain Behav Immun 61:1-11. https://doi.org/10.1016/j.bbi.2016.07.003

14. Ulland TK, Song WM, Huang SC et al (2017) TREM2 maintains microglial metabolic fitness in Alzheimer's disease. Cell 170:649 663.e613. https://doi.org/10.1016/j.cell.2017.07.023

15. Schmitt K, Grimm A, Kazmierczak A, Strosznajder JB, Gotz J, Eckert A (2012) Insights into mitochondrial dysfunction: aging, 
amyloid-beta, and tau-a deleterious trio. Antioxid Redox Signal 16: 1456-1466. https://doi.org/10.1089/ars.2011.4400

16. Swerdlow RH (2018) Mitochondria and mitochondrial cascades in Alzheimer's disease. J Alzheimers Dis 62:1403-1416. https://doi. org/10.3233/jad-170585

17. Swerdlow RH, Burns JM, Khan SM (2014) The Alzheimer's disease mitochondrial cascade hypothesis: progress and perspectives. Biochim Biophys Acta 1842:1219-1231. https://doi.org/10.1016/j. bbadis.2013.09.010

18. Muller WE, Eckert A, Kurz C, Eckert GP, Leuner K (2010) Mitochondrial dysfunction: common final pathway in brain aging and Alzheimer's disease-therapeutic aspects. Mol Neurobiol 41: 159-171. https://doi.org/10.1007/s12035-010-8141-5

19. Ganguly G, Chakrabarti S, Chatterjee U, Saso L (2017) Proteinopathy, oxidative stress and mitochondrial dysfunction: cross talk in Alzheimer's disease and Parkinson's disease. Drug Des Devel Ther 11:797-810. https://doi.org/10.2147/dddt.S130514

20. Grimm A, Eckert A (2017) Brain aging and neurodegeneration: from a mitochondrial point of view. J Neurochem 143:418-431. https://doi.org/10.1111/jnc.14037

21. Manczak M, Anekonda TS, Henson E, Park BS, Quinn J, Reddy PH (2006) Mitochondria are a direct site of A beta accumulation in Alzheimer's disease neurons: implications for free radical generation and oxidative damage in disease progression. Hum Mol Genet 15:1437-1449. https://doi.org/10.1093/hmg/ddl066

22. Jacobs KM, Pennington JD, Bisht KS, Aykin-Burns N, Kim HS, Mishra M, Sun L, Nguyen P et al (2008) SIRT3 interacts with the daf-16 homolog FOXO3a in the mitochondria, as well as increases FOXO3a dependent gene expression. Int J Biol Sci 4:291-299. https://doi.org/10.7150/ijbs.4.291

23. Kincaid B, Bossy-Wetzel E (2013) Forever young: SIRT3 a shield against mitochondrial meltdown, aging, and neurodegeneration. Front Aging Neurosci 5:48. https://doi.org/10.3389/fnagi.2013. 00048

24. Cheng Y, Ren X, Gowda AS, Shan Y, Zhang L, Yuan YS, Patel R, $\mathrm{Wu} \mathrm{H}$ et al (2013) Interaction of Sirt3 with OGG1 contributes to repair of mitochondrial DNA and protects from apoptotic cell death under oxidative stress. Cell Death Dis 4:e731. https://doi.org/10. 1038/cddis.2013.254

25. Tang X, Ma H, Han L et al (2016) SIRT1 deacetylates the cardiac transcription factor $\mathrm{Nkx} 2.5$ and inhibits its transcriptional activity. Sci Rep 6:36576. https://doi.org/10.1038/srep36576

26. Jesko H, Strosznajder RP (2016) Sirtuins and their interactions with transcription factors and poly(ADP-ribose) polymerases. Folia Neuropathol 54:212-233

27. Jesko H, Wencel P, Strosznajder RP, Strosznajder JB (2017) Sirtuins and their roles in brain aging and neurodegenerative disorders. Neurochem Res 42:876-890. https://doi.org/10.1007/s11064016-2110-y

28. Zhou Y, Wang S, Li Y, Yu S, Zhao Y (2017) SIRT1/PGC-1alpha signaling promotes mitochondrial functional recovery and reduces apoptosis after intracerebral hemorrhage in rats. Front Mol Neurosci 10:443. https://doi.org/10.3389/fnmol.2017.00443

29. Julien C, Tremblay C, Emond V, Lebbadi M, Salem N Jr, Bennett DA, Calon F (2009) Sirtuin 1 reduction parallels the accumulation of tau in Alzheimer disease. J Neuropathol Exp Neurol 68:48-58. https://doi.org/10.1097/NEN.0b013e3181922348

30. Yin J, Han P, Song M, Nielsen M, Beach TG, Serrano GE, Liang WS, Caselli RJ et al (2018) amyloid-beta increases tau by mediating sirtuin 3 in Alzheimer's disease. Mol Neurobiol 55:8592-8601. https://doi.org/10.1007/s12035-018-0977-0

31. Chen J, Zhou Y, Mueller-Steiner S, Chen LF, Kwon H, Yi S, Mucke L, Gan L (2005) SIRT1 protects against microglia-dependent amyloidbeta toxicity through inhibiting NF-kappaB signaling. J Biol Chem 280:40364 40374. https://doi.org/10.1074/jbc.M509329200
32. Gomes BAQ, Silva JPB, Romeiro CFR, Dos Santos SM, Rodrigues CA, Gonçalves PR, Sakai JT, Mendes PFS et al (2018) Neuroprotective mechanisms of resveratrol in Alzheimer's disease: Role of SIRT1. Oxidative Med Cell Longev 2018:8152373. https://doi.org/10.1155/2018/8152373

33. Wenz T (2011) Mitochondria and PGC-1alpha in aging and ageassociated diseases. J Aging Res 2011:810619. https://doi.org/10. 4061/2011/810619

34. Mossmann D, Vogtle FN, Taskin AA et al (2014) Amyloid-beta peptide induces mitochondrial dysfunction by inhibition of preprotein maturation. Cell Metab 20:662-669. https://doi.org/10. 1016/j.cmet.2014.07.024

35. Bartolome F, de la Cueva M, Pascual C, Antequera D, Fernandez T, Gil C, Martinez A, Carro E (2018) Amyloid beta-induced impairments on mitochondrial dynamics, hippocampal neurogenesis, and memory are restored by phosphodiesterase 7 inhibition. Alzheimers Res Ther 10:24-15. https://doi.org/10.1186/s13195-018-0352-4

36. Manczak M, Calkins MJ, Reddy PH (2011) Impaired mitochondrial dynamics and abnormal interaction of amyloid beta with mitochondrial protein Drp1 in neurons from patients with Alzheimer's disease: implications for neuronal damage. Hum Mol Genet 20:24952509. https://doi.org/10.1093/hmg/ddr139

37. Kandimalla R, Reddy PH (2016) Multiple faces of dynamin-related protein 1 and its role in Alzheimer's disease pathogenesis. Biochim Biophys Acta 1862:814-828. https://doi.org/10.1016/j.bbadis. 2015.12.018

38. Kuruva CS, Manczak M, Yin X, Ogunmokun G, Reddy AP, Reddy PH (2017) Aqua-soluble DDQ reduces the levels of Drp1 and Abeta and inhibits abnormal interactions between Abeta and Drp1 and protects Alzheimer's disease neurons from Abeta- and Drp1induced mitochondrial and synaptic toxicities. Hum Mol Genet 26: 3375-3395. https://doi.org/10.1093/hmg/ddx226

39. Zolezzi JM, Silva-Alvarez C, Ordenes D, Godoy JA, Carvajal FJ, Santos MJ, Inestrosa NC (2013) Peroxisome proliferator-activated receptor (PPAR) gamma and PPARalpha agonists modulate mitochondrial fusion-fission dynamics: relevance to reactive oxygen species (ROS)-related neurodegenerative disorders? PLoS One 8: e64019. https://doi.org/10.1371/journal.pone.0064019

40. Manczak M, Kandimalla R, Yin X, Reddy PH (2019) Mitochondrial division inhibitor 1 reduces dynamin-related protein 1 and mitochondrial fission activity. Hum Mol Genet 28:177-199. https://doi.org/10.1093/hmg/ddy335

41. Zhang L, Trushin S, Christensen TA, Bachmeier BV, Gateno B, Schroeder A, Yao J, Itoh K et al (2016) Altered brain energetics induces mitochondrial fission arrest in Alzheimer's Disease. Sci Rep 6:18725. https://doi.org/10.1038/srep18725

42. Chen H, McCaffery JM, Chan DC (2007) Mitochondrial fusion protects against neurodegeneration in the cerebellum. Cell 130: 548-562. https://doi.org/10.1016/j.cell.2007.06.026

43. Youle RJ, van der Bliek AM (2012) Mitochondrial fission, fusion, and stress. Science 337:1062-1065. https://doi.org/10.1126/ science. 1219855

44. Manczak M, Kandimalla R, Fry D, Sesaki H, Reddy PH (2016) Protective effects of reduced dynamin-related protein 1 against amyloid beta-induced mitochondrial dysfunction and synaptic damage in Alzheimer's disease. Hum Mol Genet 25:51485166. https://doi.org/10.1093/hmg/ddw330

45. Czapski GA, Cieslik M, Wencel PL, Wojtowicz S, Strosznajder RP, Strosznajder JB (2018) Inhibition of poly(ADP-ribose) polymerase- 1 alters expression of mitochondria-related genes in PC12 cells: relevance to mitochondrial homeostasis in neurodegenerative disorders. Biochim Biophys Acta 1865: 281-288. https://doi.org/10.1016/j.bbamcr.2017.11.003

46. Cieslik M, Czapski GA, Strosznajder JB (2015) The molecular mechanism of amyloid beta42 peptide toxicity: the role of 
sphingosine kinase-1 and mitochondrial sirtuins. PLoS One 10: e0137193. https://doi.org/10.1371/journal.pone.0137193

47. Wilkaniec A, Gassowska-Dobrowolska M, Strawski M, Adamczyk A, Czapski GA (2018) Inhibition of cyclin-dependent kinase 5 affects early neuroinflammatory signalling in murine model of amyloid beta toxicity. J Neuroinflammation 15:1. https://doi.org/10. 1186/s12974-017-1027-y

48. Hubbart BP (2017) Allosteric SIRT1 activators as putative antiaging drugs. In: Vaiserman AM (ed) Anti-aging Drugs: From Basic Research to Clinical Practice. RSC Publishing, Cambridge

49. Jaber V, Zhao Y, Lukiw WJ (2017) Alterations in micro RNAmessenger RNA (miRNA-mRNA) coupled signaling networks in sporadic Alzheimer's disease (AD) hippocampal CA1. J Alzheimers Dis Parkinsonism 7. https://doi.org/10.4172/2161-0460.1000312

50. Pogue AI, Lukiw WJ (2018) Up-regulated pro-inflammatory microRNAs (miRNAs) in Alzheimer's disease (AD) and agerelated macular degeneration (AMD). Cell Mol Neurobiol 38: 1021-1031. https://doi.org/10.1007/s10571-017-0572-3

51. Spinazzi M, Casarin A, Pertegato V, Salviati L, Angelini C (2012) Assessment of mitochondrial respiratory chain enzymatic activities on tissues and cultured cells. Nat Protoc 7:1235-1246. https://doi. org/10.1038/nprot.2012.058

52. Gueguen C, Palmier B, Plotkine M, Marchand-Leroux C, Besson VC (2014) Neurological and histological consequences induced by in vivo cerebral oxidative stress: evidence for beneficial effects of SRT1720, a sirtuin 1 activator, and sirtuin 1-mediated neuroprotective effects of poly(ADP-ribose) polymerase inhibition. PLoS One 9:e87367. https://doi.org/10.1371/journal.pone.0087367

53. Lassmann H, van Horssen J (2016) Oxidative stress and its impact on neurons and glia in multiple sclerosis lesions. Biochim Biophys Acta 1862:506-510. https://doi.org/10.1016/j.bbadis.2015.09.018

54. Christen Y (2000) Oxidative stress and Alzheimer disease. Am J Clin Nutr 71:621s-629s. https://doi.org/10.1093/ajen/71.2.621s

55. Nunomura A, Perry G, Aliev G et al (2001) Oxidative damage is the earliest event in Alzheimer disease. J Neuropathol Exp Neurol 60: 759-767

56. Perry G, Cash AD, Smith MA (2002) Alzheimer disease and oxidative stress. J Biomed Biotechnol 2:120-123. https://doi.org/10. 1155/s1110724302203010

57. Smith MA, Rottkamp CA, Nunomura A, Raina AK, Perry G (2000) Oxidative stress in Alzheimer's disease. Biochim Biophys Acta 1502:139-144

58. Strosznajder JB, Czapski GA, Adamczyk A, Strosznajder RP (2012) Poly(ADP-ribose) polymerase-1 in amyloid beta toxicity and Alzheimer's disease. Mol Neurobiol 46:78-84. https://doi.org/10.1007/s12035-012-8258-9

59. Shelat PB, Chalimoniuk M, Wang JH, Strosznajder JB, Lee JC, Sun AY, Simonyi A, Sun GY (2008) Amyloid beta peptide and NMDA induce ROS from NADPH oxidase and AA release from cytosolic phospholipase A2 in cortical neurons. J Neurochem 106:45-55. https://doi.org/10.1111/j.1471-4159.2008.05347.x

60. Maurer I, Zierz S, Moller HJ (2000) A selective defect of cytochrome c oxidase is present in brain of Alzheimer disease patients. Neurobiol Aging 21:455-462

61. Mutisya EM, Bowling AC, Beal MF (1994) Cortical cytochrome oxidase activity is reduced in Alzheimer's disease. J Neurochem 63: 2179-2184

62. Crouch PJ, Barnham KJ, Duce JA, Blake RE, Masters CL, Trounce IA (2006) Copper-dependent inhibition of cytochrome c oxidase by Abeta(1-42) requires reduced methionine at residue 35 of the Abeta peptide. J Neurochem 99:226-236. https://doi.org/10.1111/j.14714159.2006.04050.x

63. Crouch PJ, Blake R, Duce JA, Ciccotosto GD, Li QX, Barnham KJ, Curtain CC, Cherny RA et al (2005) Copper-dependent inhibition of human cytochrome $\mathrm{c}$ oxidase by a dimeric conformer of amyloid-beta1-42. J Neurosci 25:672-679. https://doi.org/10. 1523/jneurosci.4276-04.2005

64. Kirby K, Hu J, Hilliker AJ, Phillips JP (2002) RNA interferencemediated silencing of Sod2 in Drosophila leads to early adult-onset mortality and elevated endogenous oxidative stress. Proc Natl Acad Sci U S A 99:16162-16167. https://doi.org/10.1073/pnas.252342899

65. Lebovitz RM, Zhang H, Vogel H, Cartwright J Jr, Dionne L, Lu N, Huang S, Matzuk MM (1996) Neurodegeneration, myocardial injury, and perinatal death in mitochondrial superoxide dismutasedeficient mice. Proc Natl Acad Sci U S A 93:9782-9787

66. Bai P, Canto C, Oudart H et al (2011) PARP-1 inhibition increases mitochondrial metabolism through SIRT1 activation. Cell Metab 13:461-468. https://doi.org/10.1016/j.cmet.2011.03.004

67. Bell EL, Guarente L (2011) The SirT3 divining rod points to oxidative stress. Mol Cell 42:561-568. https://doi.org/10.1016/j. molcel.2011.05.008

68. Jiang M, Zheng J, Peng Q, Hou Z, Zhang J, Mori S, Ellis JL, Vlasuk GP et al (2014) Sirtuin 1 activator SRT2104 protects Huntington's disease mice. Ann Clin Transl Neurol 1:1047-1052. https://doi.org/ $10.1002 / \mathrm{acn} 3.135$

69. Mouchiroud L, Houtkooper RH, Moullan N, Katsyuba E, Ryu D, Cantó C, Mottis A, Jo YS et al (2013) The NAD(+)/sirtuin pathway modulates longevity through activation of mitochondrial UPR and FOXO signaling. Cell 154:430-441. https://doi.org/10.1016/j.cell. 2013.06.016

70. Polito LB, Albani GD (2017) Sirtuin modulation as novel neuroprotective strategy for Alzheimer's disease. In: Gozes I (ed) Neuroprotection in Alzheimer's Disease. Elsevier/Academic Press, pp 149-173

71. Van Bulck M, Sierra-Magro A, Alarcon-Gil J, Perez-Castillo A, Morales-Garcia JA (2019) Novel approaches for the treatment of Alzheimer's and Parkinson's disease. Int J Mol Sci 20. https://doi. org/10.3390/ijms20030719

72. Dang W (2014) The controversial world of sirtuins. Drug Discov Today Technol 12:e9-e17. https://doi.org/10.1016/j. ddtec.2012.08.003

73. Ekblad T, Schuler H (2016) Sirtuins are unaffected by PARP inhibitors containing planar nicotinamide bioisosteres. Chem Biol Drug Des 87:478-482. https://doi.org/10.1111/cbdd.12680

74. Wencel PL, Lukiw WJ, Strosznajder JB, Strosznajder RP (2017) Inhibition of poly(ADP-ribose) polymerase-1 enhances gene expression of selected sirtuins and APP cleaving enzymes in amyloid beta cytotoxicity. Mol Neurobiol 55:4612-4623. https://doi.org/10. 1007/s12035-017-0646-8

75. Wang X, Su B, Lee HG, Li X, Perry G, Smith MA, Zhu X (2009) Impaired balance of mitochondrial fission and fusion in Alzheimer's disease. J Neurosci 29:9090-9103. https://doi.org/10. 1523/jneurosci.1357-09.2009

76. Wang X, Su B, Zheng L, Perry G, Smith MA, Zhu X (2009) The role of abnormal mitochondrial dynamics in the pathogenesis of Alzheimer's disease. J Neurochem 109(Suppl 1):153-159. https://doi.org/10.1111/j.1471-4159.2009.05867.x

77. Lukiw WJ (2013) Circular RNA (circRNA) in Alzheimer's disease (AD). Front Genet 4:307. https://doi.org/10.3389/fgene.2013. 00307

78. O'Brien J, Hayder H, Zayed Y, Peng C (2018) Overview of microRNA biogenesis, mechanisms of actions, and circulation. Front Endocrinol (Lausanne) 9:402. https://doi.org/10.3389/fendo. 2018.00402

79. Guo H, Ingolia NT, Weissman JS, Bartel DP (2010) Mammalian microRNAs predominantly act to decrease target mRNA levels. Nature 466:835-840. https://doi.org/10.1038/nature09267

Publisher's Note Springer Nature remains neutral with regard to jurisdictional claims in published maps and institutional affiliations. 